\title{
Density-dependent predation, habitat variation, and the persistence of marine bivalve prey
}

\author{
RD Seitz \\ Virginia Institute of Marine Science \\ Rom Lipcius \\ Virginia Institute of Marine Science
}

AH Hines

DB Eggleston

Follow this and additional works at: https://scholarworks.wm.edu/vimsarticles

Part of the Marine Biology Commons

\section{Recommended Citation}

Seitz, RD; Lipcius, Rom; Hines, AH; and Eggleston, DB, Density-dependent predation, habitat variation, and the persistence of marine bivalve prey (2001). Ecology, 82(9), 2435-3451.

10.1890/0012-9658(2001)082[2435:DDPHVA]2.0.CO;2

This Article is brought to you for free and open access by the Virginia Institute of Marine Science at W\&M ScholarWorks. It has been accepted for inclusion in VIMS Articles by an authorized administrator of W\&M ScholarWorks. For more information, please contact scholarworks@wm.edu. 


\title{
DENSITY-DEPENDENT PREDATION, HABITAT VARIATION, AND THE PERSISTENCE OF MARINE BIVALVE PREY
}

\author{
Rochelle D. Seitz, ${ }^{1,4}$ Romuald N. Lipcius, ${ }^{1}$ Anson H. Hines, ${ }^{2}$ And David B. Eggleston ${ }^{3}$ \\ ${ }^{1}$ Virginia Institute of Marine Science, School of Marine Science, The College of William \& Mary, \\ Gloucester Point, Virginia 23062 USA \\ ${ }^{2}$ Smithsonian Environmental Research Center, P.O. Box 28, Edgewater, Maryland 21037 USA \\ ${ }^{3}$ Department of Marine, Earth and Atmospheric Sciences, North Carolina State University, \\ Raleigh, North Carolina 27695 USA
}

Abstract. The persistence of prey encountering intense predation varies by species, prey density, and habitat type; however, the collective impact of these factors has rarely been tested experimentally in natural marine systems. Using the thin-shelled clams Mya arenaria and Macoma balthica as prey, and the main epibenthic predator of whole adult clams, the blue crab Callinectes sapidus, we conducted a series of experiments in Chesapeake Bay tributaries that (1) links field abundance and distribution of bivalve prey species with habitat-specific mortality patterns; (2) represents the first comprehensive field test of species-specific, habitat-specific, and density-dependent mortality for subtidal, soft-bottom, deep-burrowing prey; and (3) thereby enables development of a conceptual model to be used as a heuristic tool linking predator-prey dynamics, habitat type, and evolutionary defense tactics for marine benthos.

In 15 years of field monitoring, Mya was more common in sand than mud habitats, and Macoma was widely distributed and at higher densities than Mya in mud and sand. In field experiments, mortality of both Mya and Macoma was density dependent in those habitats where the clams are common. The blue crab population in the field exhibited a type III "guild functional response" on Mya in sand, and on Macoma in both mud and sand. Mortality was lower in sand than mud for Mya, and similar in mud and sand for Macoma, correlating with the high abundances of Mya in sand and Macoma in sand and mud. The persistence of large juvenile and adult bivalves when confronted with intense predation derived substantially from a low-density refuge from predation that varied in a speciesspecific manner with habitat type, demonstrating the species-specific importance of density and habitat to clam survival.

We developed a conceptual model detailing the relative importance of behavior, morphology, habitat features, and the basic components of predator-prey interactions to the survival of bivalve molluscs. At one extreme are bivalve molluscs, such as oysters, that emphasize morphological refuges that increase the predator's handling time. At the other extreme are bivalves, such as Mya and Macoma, that reduce predator encounter rates. The model is intended to be used as a heuristic tool to develop testable hypotheses.

Key words: armor vs. avoidance; bivalves; blue crab; Callinectes sapidus; density dependence; sigmoid functional response; habitat type; Macoma balthica; Mya arenaria; predation; predator avoidance; low-density refuge from predation.

\section{INTRODUCTION}

Predation is a key determinant of the abundance and size structure of prey populations, as well as the structure and functioning of communities (Paine 1966, Dayton 1984, Sih et al. 1985, Menge and Sutherland 1987, Wilson 1990, Menge 1995). Survival of individuals and persistence of prey species when faced with intense predation pressure derives collectively from antipredator adaptations (Vermeij 1987), environmental conditions, habitat features (Menge and Sutherland 1976, 1987, Sih et al. 1985, Bell et al. 1991), and predator-

Manuscript received 2 June 1999; revised 2 August 2000; accepted 10 September 2000; final version received 23 October 2000 .

${ }^{4}$ E-mail: seitz@vims.edu prey dynamics (Hassell 1979, Murdoch 1994). Prey patches are selected by predators to maximize fitness or energy intake (Pyke 1984, Stephens and Krebs 1986), within the constraints of predator interference (Sih et al. 1998), predation risk, reproductive demands, avoidance of prey, chemical deterrents, and predator behavior (see Micheli 1997).

In marine ecosystems, benthic prey and their predators have served as excellent models for the study of distribution and abundance patterns, the key causes of the patterns, and the underlying mechanisms (Paine 1966, 1984, Vermeij 1987, Menge and Farrell 1989, Wilson 1990, Eggleston and Armstrong 1995, Lindquist and Hay 1995, Micheli 1997). For marine benthic predator-prey systems, there are synthetic conceptual models of antipredator adaptations (Vermeij 1987, 


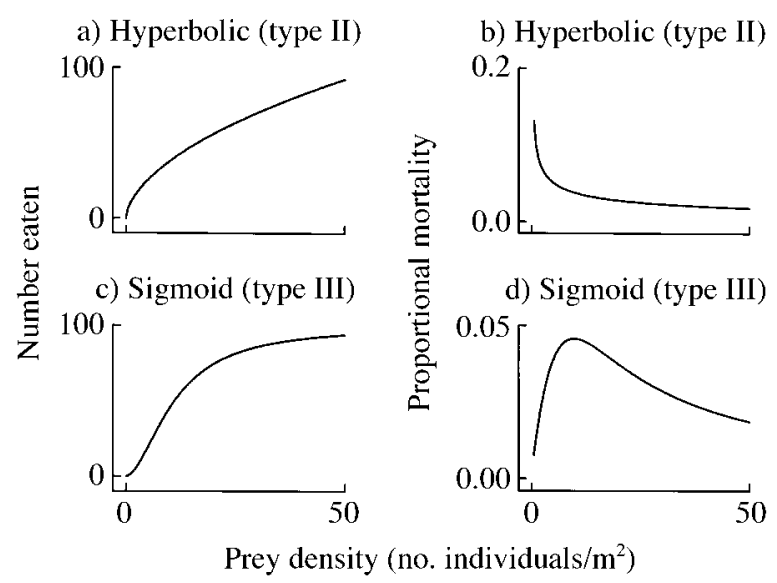

FIG. 1. Functional response curves for the number of prey eaten as a function of prey density. Curves were generated with a general model by using different values of $\beta$ for (a) hyperbolic, and (c) sigmoid relationships. (b, d) The first derivative or, as an approximation, $Y / X$, of the functional response curves depicts the proportional mortality as a function of prey density. (Modified from Lipcius et al. 1998.)

1994) and the effects of habitat features upon predatorprey interactions (Peterson 1979, Menge and Sutherland 1987, Wilson 1990, Heck and Crowder 1991), and on the evolution of predator-prey interactions (Abrams 2000). For example, Vermeij's (1987) model proposes that, through evolution, bivalves have developed either armor or locomotion to avoid predation, whereas Menge and Sutherland's (1987) consumer stress model posits that predation should be reduced as the habitat becomes more stressful to the consumer. No existing models integrate the fundamental components of predator-prey dynamics (Hassell et al. 1977) with the effects of antipredator adaptations and habitat type upon predator-prey interactions of marine benthos. Here we devise a model that encompasses these features for marine benthic systems.

\section{The functional response}

The study of consumer feeding rates concentrates on encounter rate and handling time, which change with varying prey densities. The predator's "functional response" (FR) relates the quantity of prey consumed per predator to prey density (Solomon 1949, Holling 1959). The form of the FR may be type I (linear, density independent), type II (Fig. 1a: hyperbolic, inversely density dependent), or type III (Fig. 1c; sigmoid, density dependent) (Holling 1965, Hassell 1979). Type I FRs are generally rare for predators that actively search for their prey (Hassell 1979). It can be difficult to discern between type II and type III FRs when examining the number of prey consumed (Fig. 1a, c). However, when the number of prey consumed is converted to the proportion of prey per predator, the type II and type III FRs can be readily distinguished. At low densities, the proportional mortality increases with decreasing prey density in a type II FR (Fig. 1b), but decreases with decreasing prey density in the type III FR (Fig. 1d) (Lipcius and Hines 1986, Lipcius et al. 1998). Experimentally, if the "low density" range for a particular prey species is known, then the difference between a type II and type III FR can be determined from as few as two data points within that range (Taylor and Eggleston 2000).

The form of the predator's FR can indicate whether prey persistence or local extinction would be expected. Because the per capita rate of predation is highest at low densities in the type II FR, it is destabilizing and can lead to local extinction of prey (Murdoch and Oaten 1975, Hassell 1979). The type III FR has a decreasing risk of mortality at low prey densities, thereby promoting a low-density refuge for prey (Hassell 1979), which can stabilize prey populations (Oaten and Murdoch 1975, Colton 1987). Functional responses characterized in several studies with bivalve molluscs (or other invertebrate prey) and their major predators (crabs or snails) have varied between types I, II, and III for species differing in morphology and behavior from hard-shelled or highly ornamented epifauna to thin-shelled, deep-burrowing species (Table 1).

In marine benthic systems, there are many examples of prey refuges from predation either at low densities (Lipcius and Hines 1986, Hines et al. 1997), or within inaccessible habitats (Blundon and Kennedy 1982a, $b$, Hines and Pearse 1982, Zwarts and Wanink 1991, Dittel et al. 1995, Piersma et al. 1995, Witman 1995). For example, clams attain a low-density refuge from predation by eagle rays (Hines et al. 1997). Alternatively, juvenile crabs obtain a partial refuge from cannibalistic large crabs through residence in shallow water where the feeding efficiency of larger crabs is reduced (Dittel et al. 1995). Abalones avert severe sea otter predation by residing in crevices that limit accessibility of predators (Hines and Pearse 1982), and, since these crevices are a limited resource, surviving abalones persist at low densities. Snails avoid sea star predation via residence in kelp plants and off the bottom where sea stars forage (Watanabe 1984). Microhabitat features can protect infaunal bivalves from birds; the tactile penetration of shorebirds can be limited by sediment type so that infaunal prey can achieve refuge at low density (Piersma et al. 1995). Thus, both low density and habitat refuge can promote prey persistence.

Living in aggregations is another effective predatoravoidance tactic. For example, ribbed mussels evade predation by residing in clumps that are difficult for predators to attack (Lin 1989), marsh mussels obtain refuge in aggregations (Bertness and Grosholz 1985), and oysters become less susceptible to predators when residing in clumps (Eggleston 1990a, b).

Descriptions of FRs in the literature usually pertain to only one predator (Lipcius and Hines 1986, Eggleston et al. 1992). This is a convenient determination if the experimenter is using a laboratory setting where 
TABLE 1. Investigations of density-dependent predation on benthic invertebrate prey.

\begin{tabular}{|c|c|c|c|c|c|c|}
\hline Prey species & $\begin{array}{l}\text { Mean prey } \\
\text { density } \\
\text { (no. clams } / \mathrm{m}^{2} \text { ) }\end{array}$ & Habitat & Major predators & $\begin{array}{l}\text { Functional } \\
\text { response type }\end{array}$ & Location & $\begin{array}{l}\text { Refer- } \\
\text { encest }\end{array}$ \\
\hline \multicolumn{7}{|l|}{ Infauna (deep) } \\
\hline $\begin{array}{l}\text { Mya arenaria } \\
\text { (soft-shell } \\
\text { clam) }\end{array}$ & $6-89$ & sand, mud & $\begin{array}{l}\text { Callinectes sapidus } \\
\quad \text { (blue crab) }\end{array}$ & sand: III, mud: II & lab & 1,16 \\
\hline M. arenaria & $80-320$ & sand & C. sapidus & not testable $\ddagger$ & lab & 2 \\
\hline M. arenaria & $6-67$ & sand, mud & C. sapidus§ & sand: III, mud: II & field & 3 \\
\hline $\begin{array}{c}\text { Macoma balthica } \\
\text { (Baltic clam) }\end{array}$ & 4,16 & muddy sand & C. sapidus & III & lab & 4 \\
\hline M. balthica & $4-103$ & sand, mud & C. sapidus & sand, mud: III & lab & 5 \\
\hline M. balthica & 12,50 & sand, mud & C. sapidus $§$ & sand, mud: III & field & 3 \\
\hline M. balthica & $60-1200$ & mud & $\begin{array}{l}\text { Cancer magister (Dun- } \\
\text { geness crab) }\end{array}$ & III & lab & 6 \\
\hline $\begin{array}{l}\text { Paphies ventri- } \\
\text { cosa (toheroa } \\
\text { [clam]) }\end{array}$ & $500-2000$ & sand & $\begin{array}{l}\text { Ovalipes catharus (pad- } \\
\text { dle crab) }\end{array}$ & not testable $\ddagger$ & lab & 7 \\
\hline \multicolumn{7}{|l|}{ Infauna (shallow) } \\
\hline $\begin{array}{l}\text { Protothaca } \\
\text { staminea (lit- } \\
\text { tleneck clam) }\end{array}$ & $59-388$ & sand, mud & $\begin{array}{l}\text { Cancer spp. (crabs), } \\
\text { Polinices reclusianus } \\
\text { (moon snail)§ }\end{array}$ & III (occasional) & field & 8 \\
\hline P. staminea & 60,240 & pebbles and sand & Cancer spp. (crabs) $\S$ & III & field & 9 \\
\hline $\begin{array}{l}\text { Chione undatel- } \\
\text { la (clam) }\end{array}$ & $12-360$ & sand, mud & $\begin{array}{l}\text { Cancer spp., P. reclusi- } \\
\quad \text { anus } \S\end{array}$ & I & field & 8 \\
\hline $\begin{array}{l}\text { Cerastoderma } \\
\text { edule (cockle) }\end{array}$ & $0-1600$ & sand flats & $\begin{array}{l}\text { Haematopus ostralegus } \\
\text { (oystercatcher) } \S\end{array}$ & III & field & 10 \\
\hline $\begin{array}{l}\text { Rangia cuneata } \\
\text { (wedge clam) }\end{array}$ & $80-320$ & sand & C. sapidus & not testable $\ddagger$ & lab & 2 \\
\hline $\begin{array}{l}\text { Mercenaria } \\
\text { mercenaria } \\
\text { (hard clam) }\end{array}$ & $24-120$ & sand, sand/shell & $\begin{array}{l}\text { Ovalipes ocellatus (lady } \\
\text { crab) }\end{array}$ & $\begin{array}{l}\text { sand: II, sand/ } \\
\text { shell: I }\end{array}$ & lab & 11 \\
\hline $\begin{array}{l}\text { M. mercenaria } \\
\text { (hard clam) }\end{array}$ & 10,50 & sand & $\begin{array}{l}\text { Callinectes sapidus } \\
\text { (blue crab) }\end{array}$ & III & $\begin{array}{l}\text { field } \\
\text { enclosure }\end{array}$ & 12 \\
\hline \multicolumn{7}{|l|}{ Epifauna (motile) } \\
\hline $\begin{array}{l}\text { Placopecten } \\
\text { magellanicus } \\
\text { (sea scallop) }\end{array}$ & $0.1-37$ & cobble, shell, silt & $\begin{array}{l}\text { Asterias vulgaris, } A . \\
\quad \text { forbesi (sea stars) }\end{array}$ & I & field & 13 \\
\hline $\begin{array}{l}\text { P. magellanicus } \\
\text { (sea scallop) }\end{array}$ & $0.1-37$ & cobble, shell, silt & $\begin{array}{l}\text { Cancer irroratus (rock } \\
\text { crab) } \S\end{array}$ & III & field & 13 \\
\hline \multicolumn{7}{|l|}{ Epifauna (sessile) } \\
\hline $\begin{array}{l}\text { Balanus bala- } \\
\text { noides (barna- } \\
\text { cle) }\end{array}$ & $4-64$ & rocky intertidal & $\begin{array}{l}\text { Urosalpinx cinerea } \\
\quad \text { (oyster drill) }\end{array}$ & II & field & 14 \\
\hline $\begin{array}{l}\text { Crassostrea } \\
\text { virginica } \\
\text { (American } \\
\text { oyster) }\end{array}$ & $15-150$ & oyster shell & $\begin{array}{l}\text { C. sapidus } \\
\text { (blue crab) }\end{array}$ & II & lab & 15 \\
\hline
\end{tabular}

Notes: Deep-burrowing infaunal prey are typically thin-shelled and do not achieve a relative size refuge from predation (Blundon and Kennedy 1982a, b). Epifaunal prey have thicker shells and are representative of species utilizing armor and size refuges from predation (Vermeij 1987). Shallow-burrowing infauna or motile epifauna are typically intermediate to the extreme groups in shell thickness and ornamentation.

$\dagger 1$, Lipcius and Hines (1986); 2, Ebersole and Kennedy (1995); 3, present study; 4, Mansour and Lipcius (1991); 5, Eggleston et al. (1992); 6, Iribarne et al. (1995); 7, Haddon et al. (1987); 8, Peterson (1982b); 9, Boulding and Hay (1984); 10, Horwood and Goss-Custard (1977); 11, Sponaugle and Lawton (1990); 12, Micheli (1997); 13, Barbeau et al. (1994);

14, Katz (1985); 15, Eggleston (1990a, b); 16, Taylor and Eggleston (1999).

\$ Experimental prey densities were too high to test for density dependence.

$\S$ Major predators in field studies have been identified by the respective authors through behavioral observations, stomach content analyses, or shell breakage patterns of dead or surviving prey.

the predator is controlled. However, in the field it is necessary to distinguish the response of the predator guild from that of one predator. Thus, we define the functional response of the natural predator guild in the field as the "guild functional response," which can be described as type I, II, or III. Although different pred- ator species may have different functional response curves, if there is a single dominant predator species, the guild functional response of multiple individuals of that species in the field may be similar to the functional response of a single individual in laboratory experiments (e.g., Eggleston et al. 1992). Alternatively, 

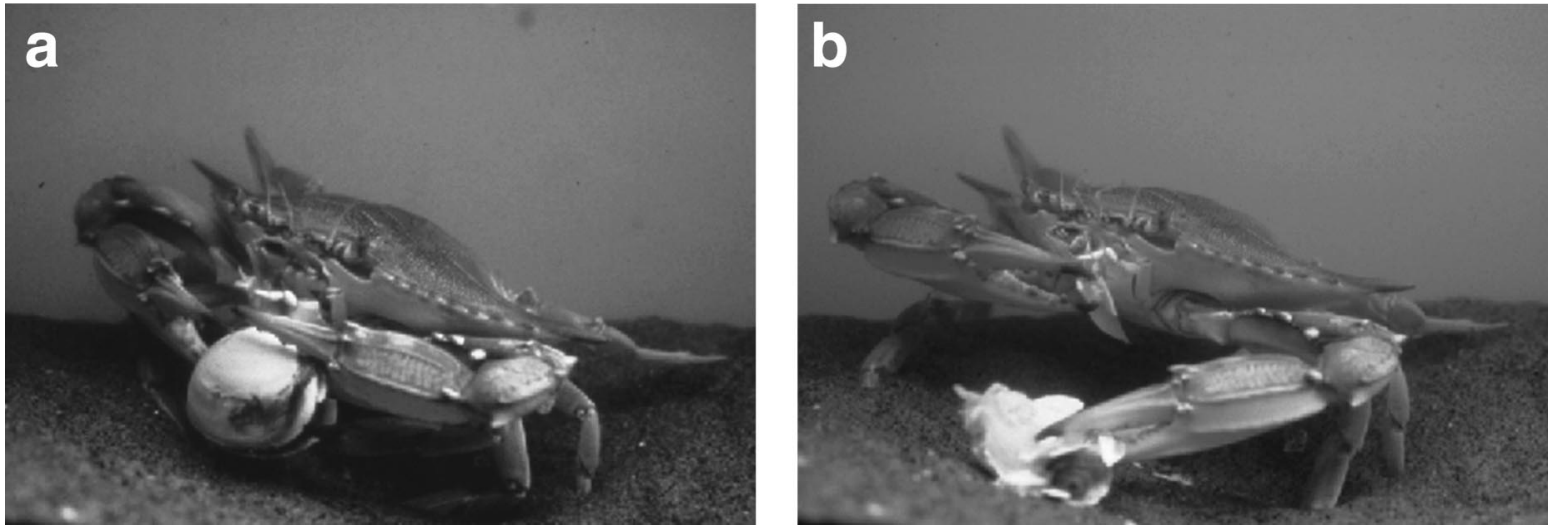

Plate 1. (a) A blue crab (Callinectes sapidus) encountered and removed a thin-shelled clam (Mya arenaria) from a sandy sediment. (b) The blue crab handled, manipulated, and consumed the clam.

the guild functional response may be unlike a single predator's FR if there are multiple predators with differing FRs in the field.

\section{Predators and prey in Chesapeake Bay}

In Chesapeake Bay, dominant epibenthic predators include the blue crab, Callinectes sapidus, as well as various demersal fishes (Horwitz 1987, Hines et al. 1990), while the benthic prey assemblages are dominated numerically by infaunal polychaetes and in biomass by bivalves (Boesch 1977, Virnstein 1977, Hines et al. 1990). The thin-shelled infaunal bivalves Mya arenaria and Macoma balthica are common and abundant throughout Chesapeake Bay (Holland 1985, Boesch 1977), and constitute a large percentage of the blue crab diet (Laughlin 1982, Hines et al. 1990, Mansour and Lipcius 1991, Mansour 1992). Despite intense predation by blue crabs, Mya persists in sandy habitats, whereas Macoma exists in both sandy and muddy habitats (Eggleston et al. 1992).

Differential abundance of bivalves by sediment type might be due to physical properties of the sediment, food availability, the geochemical environment, or changes in predator-prey relationships. Sediment composition alone can favor survival of one trophic group over another (Rhoads and Young 1970). For instance, clogging of the feeding apparatus in a suspension feeder such as Mya may preclude its survival in muddy habitats, whereas the facultative deposit feeder $M a$ coma can feed in sand or mud, but with differing efficiencies (Lipcius and Hines 1986). Differential distributions of these clams can be suggestive of differing refuge properties of each sediment, among other factors (Lipcius and Hines 1986, Eggleston et al. 1992).

The prevalence of infaunal suspension-feeding bivalves such as Mya in sandy sediments (Hines and Comtois 1985) suggests that survival may depend, in part, upon reduced mortality at a low-density refuge in those sediments (Lipcius and Hines 1986). Reduced penetrability of sandy sediments, sufficient burial depth, reduced predator activity, and low encounter rate are the potential mechanisms maintaining this refuge (Lipcius and Hines 1986, Eggleston et al. 1992). Burial to depths $>15 \mathrm{~cm}$ (Blundon and Kennedy $1982 \mathrm{~b}$, Ebersole and Kennedy 1995), residence in low-density patches (Eggleston et al. 1992), and mutual interference between foraging crabs (Mansour and Lipcius 1991, Clark et al. 1999b) provide relative refuges from predation by crabs upon Macoma.

The blue crab Callinectes sapidus Rathbun (Arthropoda: Crustacea: Portunidae) is abundant throughout Chesapeake Bay (Williams 1984, Hines et al. 1987, 1990, Lipcius and Van Engel 1990). Feeding efficiency and prey capture in blue crabs vary significantly with prey availability, predator density, and habitat complexity (Blundon and Kennedy 1982a, b. Arnold 1984, Lipcius and Hines 1986, West and Williams 1986, Eggleston 1990a, Hines et al. 1990, Mansour and Lipcius 1991, Eggleston et al. 1992, Micheli 1997). The diet of blue crabs, however, consists mainly of bivalve molluscs, predominantly Mya and Macoma, and conspecifics, as well as polychaetes, other crabs, and fish (Laughlin 1982, Alexander 1986, Hines et al. 1990, Mansour 1992, Ebersole and Kennedy 1995). Although epibenthic fishes exert sublethal predation on clams through siphon nipping (Peterson and Skilleter 1994), and juvenile clams may be eaten by fish, polychaetes, or nemertines, the blue crab is the only predator of whole adult clams within the Chesapeake Bay predator guild at our sites (Hines et al. 1990), and is therefore likely responsible for the guild functional response in our system (see Plate 1).

In laboratory experiments, a refuge from predation existed for clams at low densities due to the type III FR of blue crabs to Macoma and Mya in sand, and to Macoma in mud; there was a decreasing risk of mortality with a decrease in prey density, a pattern consistent with prey persistence in these habitats (Lipcius and Hines 1986, Eggleston et al. 1992). For Mya in mud, the response was type II, such that the risk of 
mortality was highest at low prey densities, consistent with local extinction. The low-density refuges in sand and mud were contingent upon attainment of a burial depth of 10-15 cm, below which little mortality occurred; this depth correlates directly with clam size (Blundon and Kennedy 1982a, b, Hines and Comtois 1985).

\section{Objectives}

Our investigation encompassed a series of field experiments that tested the inferences of laboratory experiments that demonstrated density-dependent and habitat-specific predation of blue crabs on Mya and Macoma (Lipcius and Hines 1986, Mansour and Lipcius 1991, Eggleston et al. 1992). First, we conducted long-term sampling of Mya and Macoma in different sediment types within representative habitats of Chesapeake Bay to quantify species- and habitat-specific differences in distribution of prey through time. Second, we determined predation (mortality) rates upon Mya and Macoma in the field at different clam densities in mud and sand (1987 and 1988 prey density-sediment experiments). Next, we determined predation rates on Mya in sand at three relatively low prey densities to test for a low-density refuge from predation in the field (1988 Mya density experiment). Finally, we present a generalized conceptual model detailing the relative importance of behavior, morphology, habitat features, and the basic components of predator-prey interactions to the survival and persistence of bivalves.

\section{Methods}

\section{Field densities of clams}

To quantify long-term fluctuations in abundance and background densities of clams in mud and sand habitats, clam density was measured one or two times quarterly at four sites (two in mud and two in sand sediments) in the Rhode River subestuary ( $38^{\circ} 51^{\prime} \mathrm{N}, 76^{\circ} 32^{\prime}$ W) of Chesapeake Bay (Fig. 2) during October 1979November 1993. Sites were in shallow habitats $(<4 \mathrm{~m}$ depth), and mud sites were composed of $8 \%$ sand and $92 \%$ silt and clay, while sand sites were composed of $11 \%$ gravel, $69 \%$ sand, and $20 \%$ silt and clay, on average. A set of 7-10 cores $0.008 \mathrm{~m}^{2} \times 35 \mathrm{~cm}$ deep was taken monthly by scuba divers at haphazardly selected locations within each site and averaged for one value for each site for each time period. The four to eight time periods per year were averaged for one value per site per habitat annually. Ten cores were taken during 1979-1984, but this effort was reduced when rarefaction analysis indicated that seven cores were sufficient. Cores were sieved though $0.5 \mathrm{~mm}$ mesh, fixed in $10 \%$ formaldehyde with rose bengal stain, and all Macoma balthica and Mya arenaria were counted and shell lengths measured. For the long-term data, we were only interested in comparing the habitat effects (i.e., sand vs. mud) for each species, as well as species differences (i.e., Mya vs. Macoma) within each habitat. We therefore conducted a conservative set of pairwise $t$ tests by adjusting the $\alpha$ value using the Bonferroni correction (Underwood 1997). In this case, the adjusted $\alpha=0.003$ for each test to reject at a nominal $\alpha=0.05$.

\section{Clam mortality by species, sediment type, and density}

Prey density-sediment experiments were conducted at the Rhode River sites (Fig. 2) in 1987 and 1988 to test the effects of clam species, sediment type, and density on clam vulnerability to predation. Similar collection and handling techniques were used for all manipulative experiments, as follows (see Table 2 for summary of experimental design). Clams were collected using a suction sampler (Hines et al. 1990, Eggleston et al. 1992). The sizes of clams used in the experiments were based on random samples of clams suction sampled from sediments in the area of the experimental plots; these showed natural adult sizes ranging 48-64 mm shell length (mean, $56.6 \mathrm{~mm} ; 1 \mathrm{sE}, 0.96$ ) for Mya, and 19-37 mm (mean, $28.8 \mathrm{~mm}$; $1 \mathrm{SE}, 1.11$ ) for $M a$ coma. Shallow sites at $1-1.5 \mathrm{~m}$ depth were chosen in mud and sand habitats (Fig. 2). For each experiment and sediment type, three or four transects were laid out parallel to shore in the subtidal zone. For each species, Mya and Macoma, we typically used three factors (caging, clam density, and sediment type) and two levels of each factor (Table 2, Rhode River). Clams were planted in 0.5 or $0.36 \mathrm{~m}^{2}$ plots on each transect that were spaced 2-6 $\mathrm{m}$ apart, and treatments were randomly assigned to plots. Caged controls were used to exclude predators and quantify handling mortality. These 13-mm mesh cages do not markedly affect flow rates in the Rhode River, because flow is extremely low, or in the York River, where sediment deposition was similar in cages, partial cages and open plots (Seitz 1996). For each clam species, two (12 and 50 clams/ $\left.\mathrm{m}^{2}\right)$ or three $\left(6,11\right.$, and $\left.33 \mathrm{clams} / \mathrm{m}^{2}\right)$ nominal clam densities were planted to represent the low densities that persisted in our long-term population data for each species. Planted clams were marked with a black " $\mathrm{X}$ " to allow them to be distinguished from natural ambient clams in the plots; ambient clam densities typically range 1-25 clams/m² (Eggleston et al. 1992).

Clams were carefully planted just below the sediment surface with the siphon upwards, relatively evenly spaced, and with care taken to leave the surrounding sediment intact. All plots were then covered with a 13$\mathrm{mm}$ mesh predator exclusion cage for an acclimation period of 24-48 h; previous laboratory trials indicated that $24 \mathrm{~h}$ was a sufficient time for clams to achieve a stable burial depth below 10-15 cm (Lipcius and Hines 1986, Eggleston et al. 1992). After acclimation, cages were removed from half of the plots (uncaged treatment), left on the other half to control for predation (caged controls), and all plots were left intact for 2$14 \mathrm{~d}$ (see Table 2, Rhode River), depending on the 


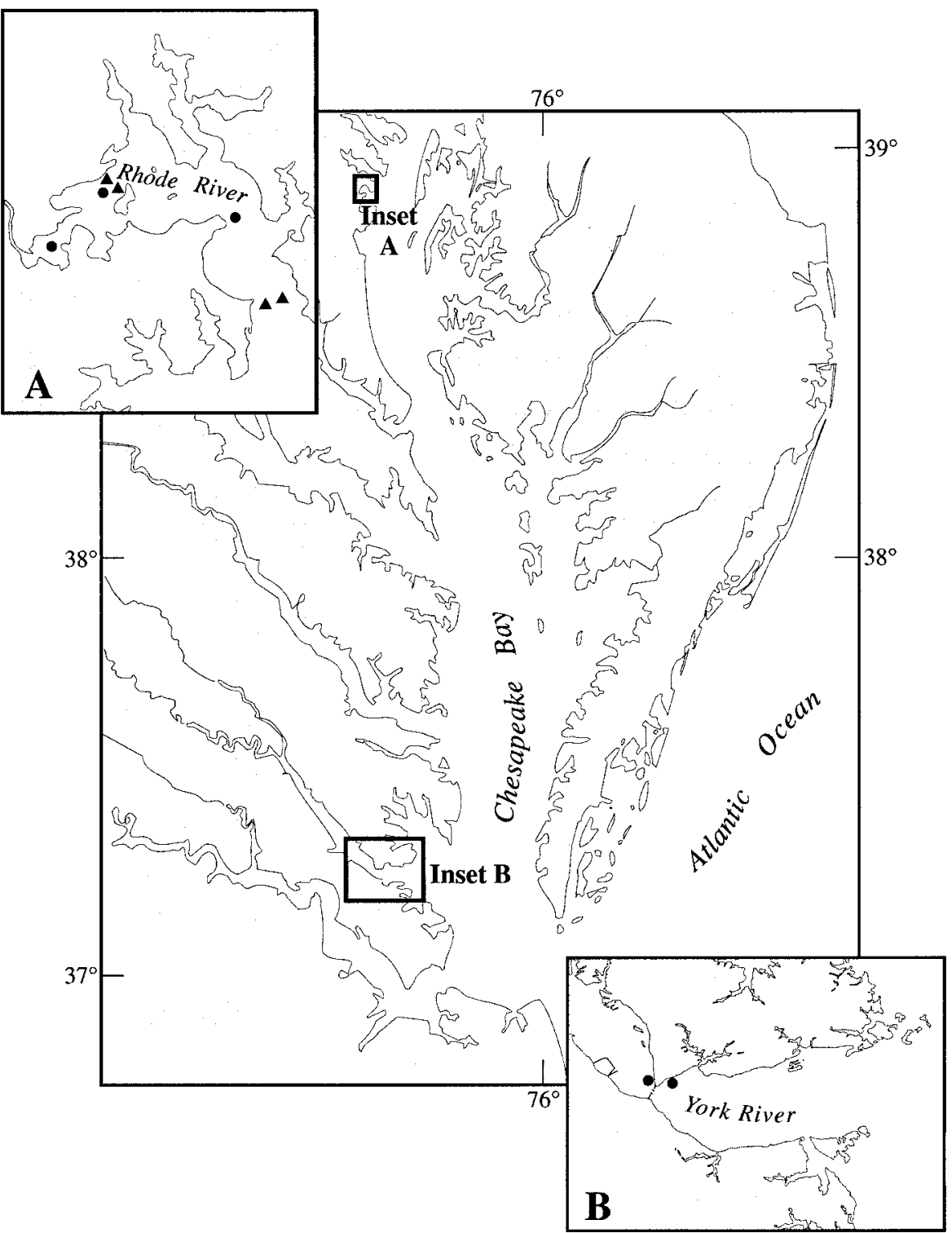

FIG. 2. Map of Chesapeake Bay and sites of long-term benthic sampling (triangles) and predation experiments (circles) at the two field locations in the (Inset A) Rhode River, Maryland, and (Inset B) York River, Virginia.

TABle 2. Summary of experimental designs in the Rhode and York Rivers.

\begin{tabular}{|c|c|c|c|c|c|c|c|}
\hline River (year) & Factors (no. levels) & Sediment & $n$ & $\begin{array}{c}\text { Plot size } \\
\left(\mathrm{m}^{2}\right)\end{array}$ & $\begin{array}{c}\text { Densities } \\
(\text { no. clams/ } \\
\left.\mathrm{m}^{2}\right)\end{array}$ & $\begin{array}{l}\text { Accli- } \\
\text { mation } \\
\text { period } \\
\text { (h) }\end{array}$ & $\begin{array}{l}\text { Exposure } \\
\text { period (d) }\end{array}$ \\
\hline Rhode $(1987) \dagger$ & density (2), sediment (2), cage (2) & sand, mud & 3 & 0.5 & 12,50 & 48 & 6 \\
\hline Rhode $(1988) \ddagger$ & density (2), sediment (2), cage (2) & sand, mud & Myа 3 & 0.5 & 12,50 & 24 & 8 \\
\hline Rhode $(1988) \ddagger$ & density (2), sediment (2), cage (2) & sand, mud & Macoma 7 & 0.5 & 12,50 & & \\
\hline York $(1988) \S$ & density (3), cage (2) & sand & 7 & 0.36 & $17,33,67$ & 48 & 2 \\
\hline York (1988)\| & density (3), cage (2) & sand & 7 & 0.36 & $6,11,33$ & 48 & $2,5,14$ \\
\hline
\end{tabular}

$\dagger$ Prey density-sediment type experiment (Fig. 4).

† Prey density-sediment type experiment (Fig. 5).

$\S$ Mya prey density pilot experiment in sand (Fig. 7).

\| Mya prey density full experiment in sand (Figs. 6 and 7). 
experiment (values were converted to proportional mortality per square meter per day to allow comparison between experiments). After exposure to predation, contents of all caged and uncaged plots were extracted to a depth of $40 \mathrm{~cm}$ using a suction sampler, and both marked and unmarked Mya and Macoma in those samples were enumerated. Marked shells with characteristic breakage were noted as indicative of crab predation. For each plot, we accounted for the umbo of each marked clam upon recapture.

To determine proportional mortalities and any effects of handing or physical stress, we used data from both caged and uncaged plots. Survival of caged marked clams allowed for detection of handing mortality as well as efficiency of clam recapture. An ANOVA model comparing mortalities of caged control clams between both sediments was nonsignificant for Mya $(P=0.54)$ and slightly nonsignificant for Macoma $(P=0.10)$. However, differences in physical effects between sediments were taken into account since control mortalities were subtracted from treatment mortalities. Proportional mortality was, thus, determined as the proportion of dead uncaged clams minus the proportion of dead caged clams. Proportional mortalities were arcsine square-root transformed to attain normality and homogeneity of variance (Cochran's $C$ test; Sokal and Rohlf 1981, Underwood 1997). Data were then subjected to multiway ANOVA models with year, species, sediment, and density as factors. When multiple comparison tests were required (i.e., for pairwise tests between factor levels when interaction effects were significant, or when there were more than two levels of a factor), we used the Student-Newman-Keuls (SNK) test, which is powerful (Underwood 1997) and not susceptible to type I error when there are few treatment levels (A. J. Underwood, personal communication).

\section{Density-dependent mortality of Mya in sand}

In a 1988 Mya density experiment, we tested for a low-density refuge from predation for Mya in sand habitats, because previous laboratory experiments indicated a refuge from predation in sand, but not in mud (Lipcius and Hines 1986). Functional response models of blue crab predation on infauna predict that refuge effectiveness is evident only at low prey densities, well below predator satiation (Lipcius and Hines 1986, Eggleston et al. 1992). Due to high background densities of Mya during the experimental period in the Rhode River, and the consequent inability to maintain low experimental densities in the field, this experiment was conducted during August-October 1988 in the York River, Virginia, where background densities of Mya were low (0-5 $\mathrm{m}^{2}$; Mansour 1992). Sediment composition of the sand habitat was $84 \%$ sand, $16 \%$ silt and clay (Seitz 1996). Hence, we used a pilot experiment to determine prey densities that would be below a lowdensity level of persistence, then a main experiment incorporating that low-to-moderate range of clam densities.

In the pilot study, to test for a low-density level of prey persistence, we planted 6,12 , and 24 clams into $0.36-\mathrm{m}^{2}$ plots yielding approximately 17, 33, and 67 clams $/ \mathrm{m}^{2}$ (Table 2, York River). Adult clams (55-70 $\mathrm{mm}$ in length) were obtained from commercial distributors in Maryland. Proportional mortalities in the 67clams $/ \mathrm{m}^{2}$ treatment were high, measuring much above those observable near the low-density level. Therefore, in the main experiment we used lower clam densities of 2, 4, and 12 clams/plot or 6, 11, and $33 \mathrm{clams} / \mathrm{m}^{2}$ (Table 2, York River). Cages were removed from half of the paired plots, and all plots were left exposed for either $2 \mathrm{~d}$ (trial 1, 26-28 September), $5 \mathrm{~d}$ (trial 2, 310 October), or $14 \mathrm{~d}$ (trial 3, 10-26 October). The duration of plot exposure to predation was increased as predation rates declined along with decreasing water temperatures in the fall (Eggleston 1990b); the data were subsequently normalized to clam mortality per day. The effect of density was tested using a one-way ANOVA of arcsine square-root transformed proportional mortality data. We used a linearized Ricker equation, $\ln (R / S)=\ln (a)-b S$, where $R$ is proportional mortality, and $S$ is clam density (Ricker 1975), analyzed with least-squares regression to determine the theoretical proportional mortality curve.

\section{RESUlts}

\section{Field densities of clams}

Long-term variation in densities of adult clams in the Rhode River differed significantly by species and sediment type during 1979-1993 (Fig. 3, Table 3). Whereas Mya was significantly more abundant in sand than mud (Fig. 3a, b, Table 3), Macoma was more abundant in mud than sand (Fig. 3c, d, Table 3), though the difference between sediment types was not as great for Macoma as for Mya (Fig. 3). Moreover, Macoma was always more abundant than Mya in both sand and mud (Fig. 3, Table 3).

Significant variation in recruitment led to substantial annual variations in juvenile and adult abundances for Mya and Macoma (Fig. 3). Most notably, there was substantially lower recruitment of Mya to mud habitats than sand habitats, contributing to lower adult abundances in mud than sand (Fig. 3). Following high recruitment of juvenile Mya into sand habitats in 1986 and 1987, field abundances of adults were high in 1987 and 1988 (Fig. 3b), precluding successful utilization of low-density treatments for Mya in field experiments at the Rhode River site.

\section{Clam mortality by species, sediment type, and density}

In the 1987 prey density-sediment experiment, there were significant species and sediment main effects (Table 4), but the effect of one depended on the condition 

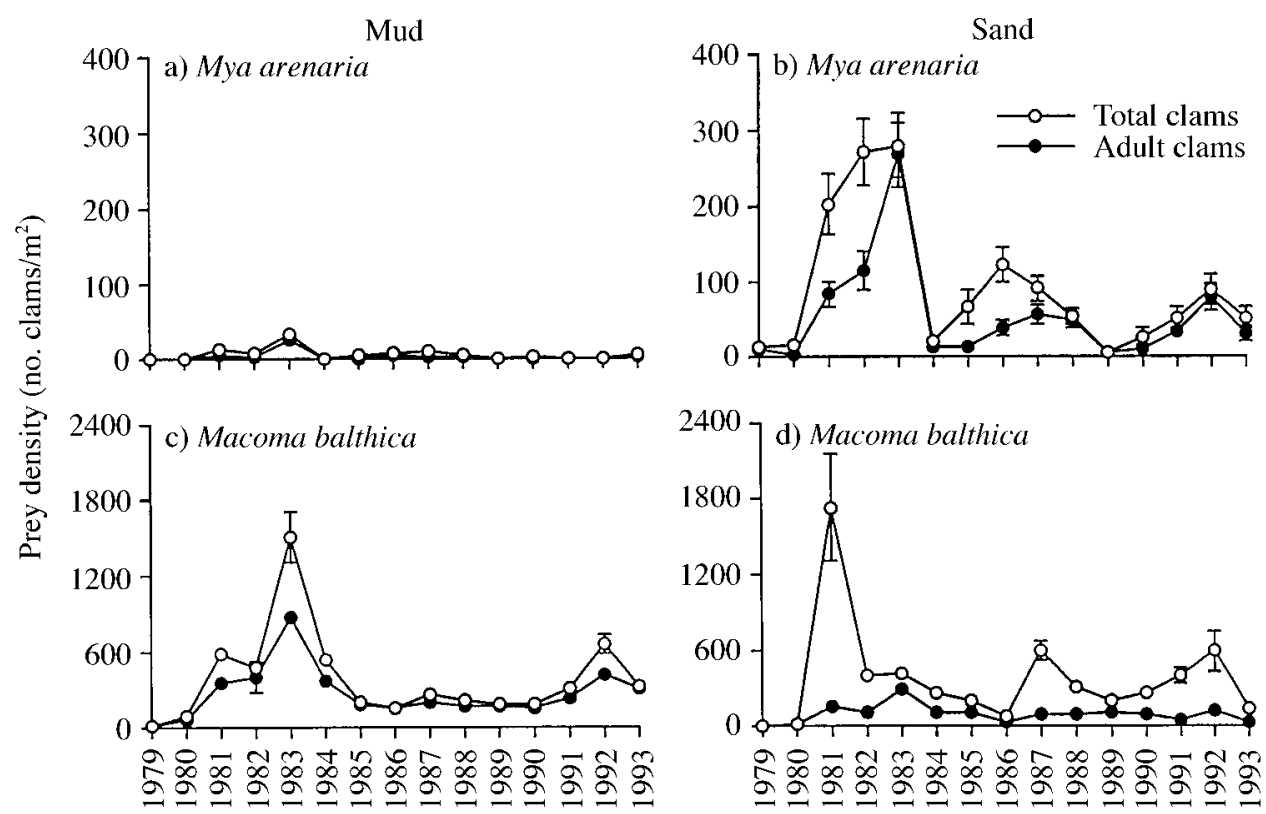

FIG. 3. Clam abundance (mean no. clams $\left./ \mathrm{m}^{2}\right)( \pm 1 \mathrm{SE})$ in the Rhode River subestuary of Chesapeake Bay for the softshell clam, Mya arenaria, in (a) mud and (b) sand, and for the tellinid bivalve Macoma balthica in (c) mud and (d) sand. Abundances of total clams (open circles) and larger juvenile and adult clams ( $>6 \mathrm{~mm}$ shell length; solid circles) are depicted.

of the other; the significant interaction effects for species $\times$ sediment and species $\times$ density precluded singular conclusions for the main effects. To examine interactions, proportional mortality of clams was analyzed at lower levels with SNK multiple comparison tests (Table 5).

For Mya, proportional mortality was significantly lower in sand than mud (Fig. 4a, Table 5), correlating with its higher abundance in sand in the field (Fig. 3a, b); nearly all clams buried in mud were eaten. Proportional mortality of Mya, however, did not differ significantly by clam density (Fig. 4a, Table 5), probably due to high ambient densities (Fig. 3). In contrast, $M a$ -

TABLE 3. Summary of multiple pairwise $t$ tests for the differences between sediment type (sand and mud) and between clam species (Mya arenaria and Macoma balthica) across two sites in sand (Sand 1 and Sand 2) and two sites in mud (Mud 1 and Mud 2) summed from all dates in a given year, for the years 1979-1993.

\begin{tabular}{ccc}
\hline \hline & \multicolumn{2}{c}{$t$ test result } \\
\cline { 2 - 3 } Effect & $P<0.003$ & $P>0.003$ \\
\hline Habitat & Macoma & Mya \\
Mud 1 vs. Sand 1 & Macoma & Mya \\
Mud 1 vs. Sand 2 & Macoma & Mya \\
Mud 2 vs. Sand 1 & Macoma & Mya \\
Mud 2 vs. Sand 2 & $\ldots$ & Macoma, Mya \\
Mud 1 vs. Mud 2 & $\ldots$ & Macoma, Mya \\
Sand 1 vs. Sand 2 & & \\
Species & Mud 1, Mud 2 & Sand 1, Sand 2 \\
Mya vs. Macoma &
\end{tabular}

Note: We used an experiment-wise error rate using the Bonferroni correction (Underwood 1997) and rejected each $t$ test at $\alpha=0.003$ for a nominal $\alpha=0.05$. coma proportional mortality did not differ between sediment types (Fig. 4b, Table 5). However, proportional mortality was significantly less at the low compared to the higher clam density (Fig. 4b, Table 5), indicating a low-density refuge from predation and a type III guild functional response, irrespective of sediment type. Moreover, proportional mortality was significantly lower in Macoma than Mya (Fig. 4, Table 5), correlating with the notably higher field abundances of $M a$ coma than Mya in both mud and sand (Fig. 3). Furthermore, predator densities are higher in mud than sand habitats in the Rhode River, but foraging efficiency is lower in mud than sand, probably due to aggressive interference between conspecifics (Seitz and Lipcius 2001).

In the 1988 prey density-sediment experiment, there were significant main effects for species and sediment and no interaction effects; proportional mortalities of Mya and Macoma were higher in mud than in sand (Fig. 5, Table 6). Moreover, Macoma suffered significantly lower mortality than $M y a$, irrespective of sediment type or clam density (Fig. 5, Table 6), as in 1987 (Fig. 4). There were no other significant main or interaction effects (Table 6).

\section{Density-dependent mortality for Mya in sand}

In the 1988 Mya density experiment, predation was density dependent on Mya in York River sand (Fig. 6, Table 7). There was a low-density refuge, since uncaged Mya suffered significantly lower mortality at the lowest density than at the highest density tested (Fig. 6 , Table 7). Mortality was negligible in caged controls 


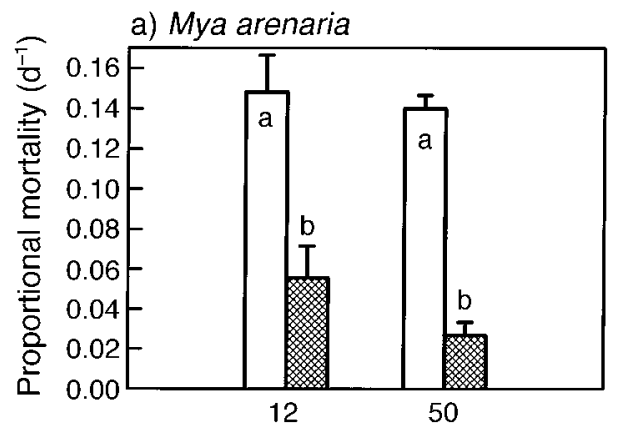

b) Macoma balthica

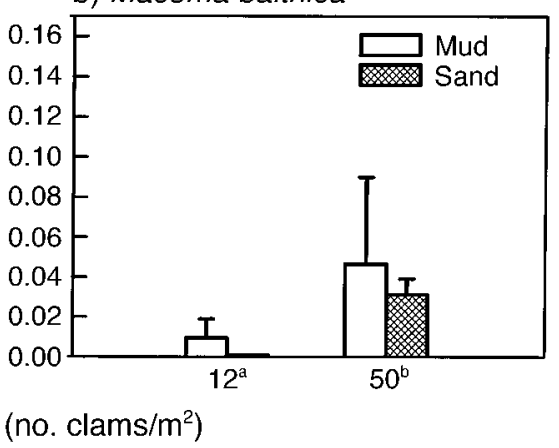

FIG. 4. Proportional mortality (back-transformed) per day (mean $+1 \mathrm{SE}$ ) of (a) Mya arenaria and (b) Macoma balthica in two habitats (mud and sand) at two nominal densities (12 and $\left.50 \mathrm{clams} / \mathrm{m}^{2}\right)$ from the 1987 prey density-sediment experiment in the Rhode River. Results of the ANOVA and SNK tests (Tables 4 and 5) are displayed; significant differences $(P<0.05)$ between levels of the main factors (species and sediment type) are indicated by dissimilar lowercase letters. Note that there was significantly lower mortality at low density for Macoma balthica.

(Fig. 6) Mathematical model fitting with SigmaPlot software was used to accommodate all of the data. Since the proportional mortality of Mya increased with density (Fig. 6), a sigmoid functional response (FR) curve fit the data (see Fig. 1c, d). A theoretical FR curve was generated by regressing all clam densities on the observed proportional mortalities (e.g., Fig. 6). A sigmoid curve (type III) provided the best fit to the data (Fig. 7a). The corresponding theoretical proportional mortality curve was generated using leastsquares regression of a Ricker model (Lipcius and Van Engel 1990):

$$
R=(0.0063)(S) \mathrm{e}^{-0.0256(S)}
$$

where $R$ is proportional mortality, and $S$ is clam density, through the entire range of densities used (6-67 clams/ $\mathrm{m}^{2}$ ) (Fig. 7b). According to the resultant curve, proportional mortality was maximal at $\sim 30 \mathrm{clams} / \mathrm{m}^{2}$ and diminished rapidly at lower densities. At higher densities (e.g., $67 \mathrm{clams} / \mathrm{m}^{2}$ ), proportional mortality rates decreased, although at a reduced rate (Fig. 7b).

\section{Discussion}

Our findings represent a field test of the joint effects of environmental features and predator-prey interac- tions upon the survival of two deep-burrowing marine species that are morphologically and phylogenetically similar (i.e., thin-shelled bivalves), and yet display contrasting distribution and abundance patterns. Fifteen years of quantitative field sampling of habitat-specific abundance and two years of field experiments on predation-induced mortality indicated consistency between abundance patterns and survival mechanisms for both bivalve species. In the mensurative field sampling, Mya and Macoma were both abundant in sand habitats, and Macoma in muds. Mya was generally absent from muds, partially due to a combination of low recruitment into that habitat and lack of a low-density refuge. Overall, the field abundance patterns were consistent with the hypothesis of density-dependent predation upon Macoma in mud and sand, and upon Mya in sand. As a caveat, there may also be issues of scale that influence survival of clams, biotic interactions such as trophic group ammensalism (Rhoads and Young 1970), or reduced fertilization success at low densities (Levitan 1991).

In the manipulative field experiments, clam survival was density- and habitat-dependent. Specifically, proportional mortalities of Macoma in both mud and sand and Mya in sand were density dependent. Proportional

TABLE 4. Three-way ANOVA of arcsine square-root transformed proportional mortality per day of clams from 1987 prey density-sediment experiments in the Rhode River.

\begin{tabular}{lcrcc}
\hline \hline \multicolumn{1}{c}{ Source of variation } & ss & df & MS & $F$ \\
\hline Species & 0.233 & 1 & 0.233 & $32.72^{* * *}$ \\
Sediment & 0.065 & 1 & 0.065 & $9.11^{* *}$ \\
Density & 0.013 & 1 & 0.013 & $1.86(\mathrm{NS})$ \\
Species $\times$ Sediment & 0.046 & 1 & 0.046 & $6.40^{*}$ \\
Species $\times$ Density & 0.046 & 1 & 0.046 & $6.51^{*}$ \\
Sediment $\times$ Density & 0.0001 & 1 & 0.0001 & 0.02 (NS) \\
Species $\times$ Sediment $\times$ Density & 0.007 & 1 & 0.007 & $1.02(\mathrm{NS})$ \\
Error & 0.114 & 16 & 0.007 & $\cdots$ \\
\hline
\end{tabular}

Notes: Factors consisted of clam species (Mya arenaria and Macoma balthica), sediment type (sand and mud), and clam density (12 clams $/ \mathrm{m}^{2}$ and $\left.50 \mathrm{clams} / \mathrm{m}^{2}\right)$. Significant interaction effects results are shown in Table 6.

$* P<0.05$, ** $P<0.01$, *** $P<0.001$; NS, $P>0.05$. 
TABLE 5. Results of the analysis of significant interaction effects of arcsine square-root transformed proportional mortality per day of clams from 1987 prey density-sediment experiments in the Rhode River (Table 4) using Student-Newman-Keuls (SNK) multiple comparisons.

\begin{tabular}{|c|c|c|c|c|}
\hline \multirow[b]{2}{*}{ Category } & \multirow[b]{2}{*}{ Factor } & \multicolumn{2}{|c|}{ Level (mean magnitude) } & \multirow{2}{*}{$\begin{array}{c}\text { SNK } \\
\text { difference }\end{array}$} \\
\hline & & (i) & (ii) & \\
\hline \multicolumn{5}{|l|}{ Species } \\
\hline \multirow[t]{2}{*}{ Mya arenaria } & sediment & sand $(0.197)$ & mud $(0.389)$ & $0.191 *$ \\
\hline & density & high $(0.273)$ & low $(0.313)$ & 0.041 (NS) \\
\hline \multirow{2}{*}{ Macoma balthica } & sediment & sand $(0.087)$ & $\operatorname{mud}(0.104)$ & 0.017 (NS) \\
\hline & density & low $(0.028)$ & high $(0.163)$ & $0.135^{*}$ \\
\hline \multicolumn{5}{|l|}{ Sediment } \\
\hline sand & species & Macoma (0.087) & Mya (0.197) & $0.110^{*}$ \\
\hline mud & species & Macoma (0.104) & Mya (0.389) & $0.285^{* *}$ \\
\hline \multicolumn{5}{|l|}{ Density } \\
\hline low & species & Macoma $(0.028)$ & Муа (0.313) & $0.285^{* *}$ \\
\hline high & species & Macoma $(0.163)$ & Mya $(0.273)$ & $0.109 *$ \\
\hline
\end{tabular}

Notes: Factors comprised clam species (Mya arenaria and Macoma balthica), sediment type (sand and mud), and clam density $\left(12 / \mathrm{m}^{2}\right.$ and $\left.50 / \mathrm{m}^{2}\right)$. Levels are arranged in order of increasing magnitude (means listed in parentheses).

$* P<0.05$; ** $P<0.01$, NS, $P>0.05$.

$\dagger$ Tested against $D_{0.05}=0.104$ and $D_{0.01}=0.142$, calculated as $D_{x}=(\text { EMS } / n)^{1 / 2}\left(q_{a}\right)$ with $n$

$=6$; error mean square $($ EMS $)=0.007$ with $16 \mathrm{df}, q_{16,2,0.05}=3.00, q_{16,2,0.01}=4.15$.

mortality of Mya in mud was high across both years, and predation was not density dependent, thereby producing no low-density refuge for Mya in mud. We suspect that the lower level of persistence in the densitydependent functional response (FR) for Mya than $M a$ coma stems from the larger body size of Mya $(\sim 70$ $\mathrm{mm}$ vs. $\sim 40 \mathrm{~mm}$ in Macoma), larger siphon size ( $\sim 5-$ $7 \mathrm{~mm}$ vs. $\sim 1-2 \mathrm{~mm}$ in Macoma) and associated higher encounter rates with tactile searching predators such as the blue crab. In sum, a low-density refuge from predation allowed clams to survive in some habitats (i.e., Macoma in mud and sand, Mya in sand) but not others, providing an explanation of habitat- and species-specific abundance patterns in the field.

\section{Persistence of thin-shelled clams}

A range of environmental and biotic factors can affect the survival of thin-shelled bivalves. For example, survival may be affected by summer anoxia (Seliger et al. 1985), tropical storms (Cory and Redding 1977), density-dependent mortality from sedimentation (Peterson and Black 1988), gradients in salinity and temperature (Ulanowicz et al. 1982), hydrodynamic processes (Matthiessen 1960, Iribarne et al. 1995), growth (Appledorn 1983), recruitment (Eggleston et al. 1992), and predation in general (Virnstein 1977, Holland et al. 1980, Commito 1982). Furthermore, we demonstrate that for our estuarine system, persistence of bi-

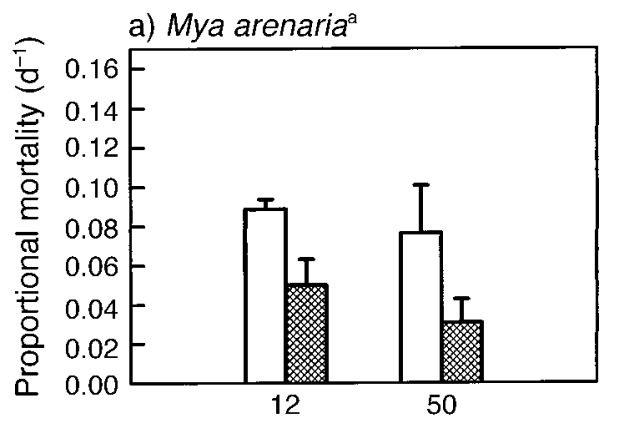

\section{b) Macoma balthica}

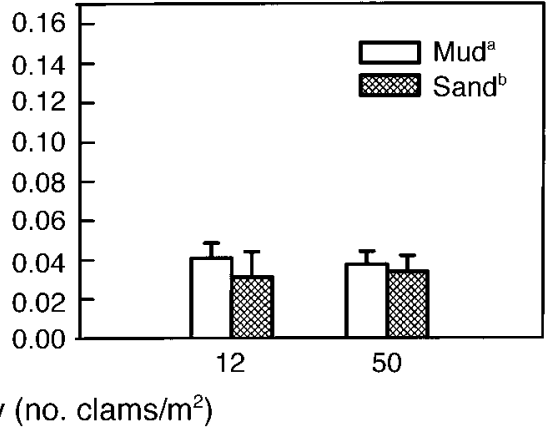

FIG. 5. Proportional mortality (back-transformed) per day (mean $+1 \mathrm{SE}$ ) of (a) Mya arenaria and (b) Macoma balthica in two habitats (mud and sand) at two nominal densities (12 and $\left.50 \mathrm{clams} / \mathrm{m}^{2}\right)$ from the 1988 prey density-sediment experiment in the Rhode River. Results of the ANOVA (Table 6) are depicted; significant differences $(P<0.05)$ between levels of the main factors (species and sediment type) are indicated by dissimilar lowercase letters. Note that in both species proportional mortality was significantly higher in mud than sand for pooled data from two densities. 
TABLE 6. Three-way ANOVA of arcsine square-root transformed proportional mortality per day of clams from 1988 prey density-sediment experiments in the Rhode River.

\begin{tabular}{lcrll}
\hline \hline \multicolumn{1}{c}{ Source of variation } & SS & df & MS & \multicolumn{1}{c}{$F$} \\
\hline Species & 0.045 & 1 & 0.045 & $6.25^{*}$ \\
Sediment & 0.044 & 1 & 0.044 & $6.22^{*}$ \\
Density & 0.002 & 1 & 0.002 & 0.33 (NS) \\
Species $\times$ Sediment & 0.006 & 1 & 0.006 & 0.81 (NS) \\
Species $\times$ Density & 0.010 & 1 & 0.010 & 1.38 (NS) \\
Sediment $\times$ Density & 0.0007 & 1 & 0.0007 & 0.10 (NS) \\
Species $\times$ Sediment $\times$ Density & 0.002 & 1 & 0.002 & 0.27 (NS) \\
Error & 0.257 & 16 & 0.007 & \\
\hline
\end{tabular}

Note: Factors consisted of clam species (Mya arenaria and Macoma balthica), sediment type (sand and mud), and clam density $\left(12 \mathrm{clams} / \mathrm{m}^{2}\right.$ and $50 \mathrm{clams} / \mathrm{m}^{2}$ ).

$* P<0.05 ;$ NS,$P>0.05$.

valves is due, in large part, to recruitment and densitydependent survival that differs by habitat.

\section{Predator foraging}

The mechanism underlying a low-density refuge from predation is the relatively lower feeding efficiency of blue crabs at such prey densities (Lipcius and Hines 1986, Mansour and Lipcius 1991, Eggleston et al. 1992, Micheli 1997), probably resulting from a reduced encounter rate with clams and concomitant threshold in foraging behavior. Based on optimal foraging behavior (Charnov 1974, Abrams 1982, 1984), we would predict that, as prey become scarce or difficult to detect, the predator would move on to more profitable patches (e.g., Clark et al. 1999a, b). Blue crabs search for prey by probing the sediment with the tips of their walking legs. Thus, reduced penetrability of the substrate (i.e., in sand or shell hash), or reduced prey densities, would reduce prey encounter rates. For example, at a constant prey density, decreased penetrability of the sediment in one habitat would reduce encounter rates with prey compared to the same prey density in an easily penetrated sediment. This reduction in encounter rates

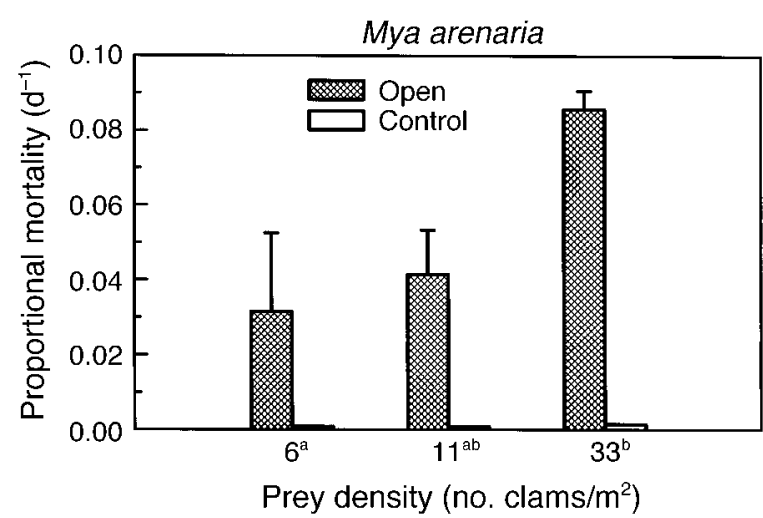

FIG. 6. Proportional mortality (back-transformed) per day (mean $+1 \mathrm{SE}$ ) of Mya arenaria in sand at three nominal densities $\left(6,11\right.$, and $\left.33 \mathrm{clams} / \mathrm{m}^{2}\right)$ from the 1988 density experiment in the York River. Results of the ANOVA and SNK tests (Table 7) are shown; significant differences $(P<$ 0.05 ) between densities are indicated by dissimilar lowercase letters. would lead to a decrease in foraging activity, further diminishing encounter rates or driving the predator from inefficient foraging areas of low prey density (Lipcius and Hines 1986). Such a low-density refuge is likely maintained even at high predator densities due to mutual interference between predators (Ens and Goss-Custard 1984, Mansour and Lipcius 1991, Micheli 1997, Clark et al. 1999b).

The recent literature on density-dependent predation elucidates some pervasive trends for benthic invertebrates (Table 1). Predators on deep-burrowing infaunal prey (e.g., Mya and Macoma) in both lab and field experiments exhibit a density-dependent FR in habitats where prey are common. A low-density refuge is attained by these prey, instead of reliance on armor for protection from predation. The FR varies with changes in sediment penetrability due to a predator's decreased encounter rate with prey in coarser sediments (Lipcius and Hines 1986, Sponaugle and Lawton 1990) and associated decreases in consumption.

Predators on shallow-burrowing prey (mainly those with thicker shells) show a range of FRs from occasional density dependence to density independence (Table 1). A predator's response to epifaunal motile species may be density dependent for shallow burrowers

TABLE 7. Student-Newman-Keuls (SNK) values for multiple comparisons of arcsine square-root transformed mean proportional mortality per day of the soft-shell clam Mya arenaria, from the 1988 Mya density experiment at the York River site.

\begin{tabular}{cc}
\hline \hline Density (no. clams $\left./ \mathrm{m}^{2}\right)$ & SNK value $\dagger$ \\
\hline 6 & $0.394^{\mathrm{a}}$ \\
11 & $0.534^{\mathrm{ab}}$ \\
33 & $0.893^{\mathrm{b}}$
\end{tabular}

Note: In this experiment, using these levels of clam density, one-way ANOVA of arcsine square-root transformed proportional mortality per day of Mya from uncaged plots yielded the following results for density (error): ss, 0.922 (2.254); MS, $0.461(0.125) ; F_{2,18}=3.68, P=0.05$.

$\dagger$ Means with dissimilar superscripts differ significantly according to the SNK tests at $P<0.05$. SNK comparisons used $D_{0.05}=0.398$ with $n=7$, when $r=2$ means apart, and $D_{0.05}$ $=0.484$ with $n=7$, when $r=3$ means apart; error mean square $=0.125$ with $\mathrm{df}=18 ; q_{18,2,0.05}=2.97 ; q_{18,3,0.05}=3.61$; see Table 5 footnotes. 
a) Mya arenaria functional response

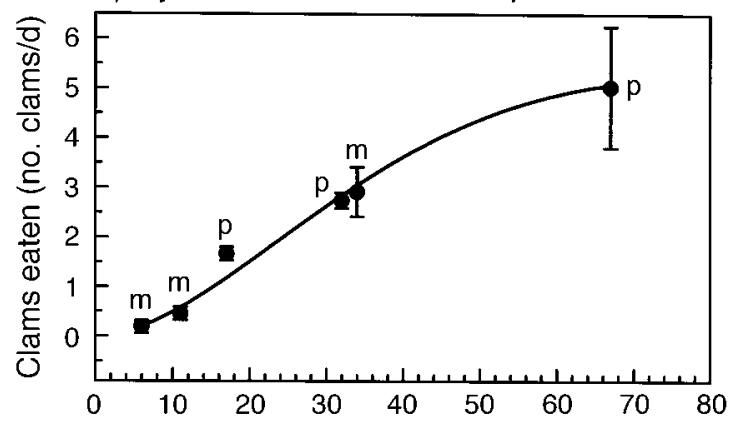

b) Mya arenaria proportional mortality

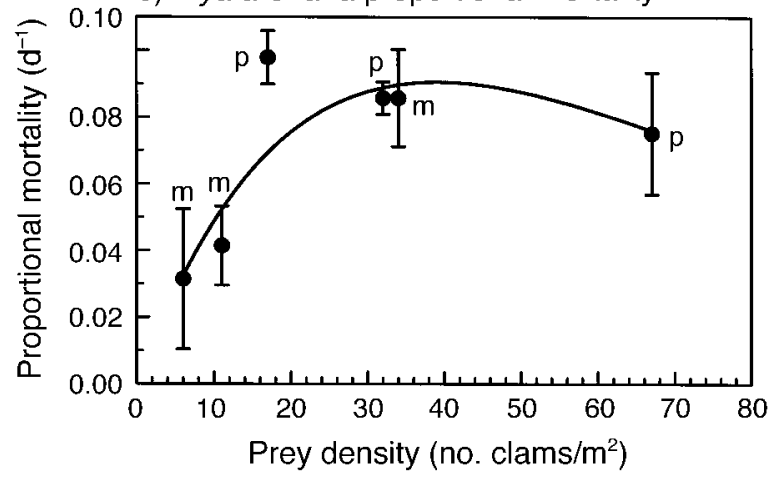

FIG. 7. (a) Functional response of predators feeding on Mya arenaria and (b) corresponding proportional mortalities of Mya arenaria from the 1988 density experiment in the York River and its pilot study. Means ( $\pm 1 \mathrm{SE}$ ) are plotted for six nominal experimental densities (no. clams $/ \mathrm{m}^{2}$ ). The theoretical curve for the sigmoid (type-III) functional response and corresponding proportional mortality curve (Ricker model) for the full range of clam densities are overlaid. Data points from the main density experiment are denoted with " $m$," and those from the pilot experiment are denoted with "p."

when handling time is less important than encounter rate (Micheli 1997). Epifaunal sessile prey are usually unable to evade predation and, therefore, must rely on armor (Vermeij 1987), habitat complexity (Eggleston $1990 a, b)$, residence in aggregations (Bertness and Grosholz 1985), and fast growth to a large size (Eggleston $1990 a, b)$ as refuges from predation.

With armored epifauna, handling time becomes the most important predator foraging concern, thus, an inversely density-dependent predator FR may be characteristic, depending upon settlement location and growth rate. For example, oysters and mussels can attain a partial predation refuge by initially settling within the interstices of clumps, and then growing fast enough to reach a size refuge by the time predators encounter them (Eggleston 1990a, b). Alternatively, oyster and mussel larvae that initially settle in vulnerable locations (e.g., the edge of an oyster shell clump) would likely suffer a predator's type II FR and local extinction.

Neither predator-prey interactions nor the corre- sponding FRs are fixed (Peterson 1982b, Lipcius and Hines 1986, Barbeau et al. 1994). These may change with different predators (Barbeau et al. 1994) or prey (Peterson 1982b). For instance, the predator-prey dynamic between scallops and their predators varied from density independent with seastar predators, to density dependent with crab predators when encounter rates were notably altered (Barbeau et al. 1994).

In general, a density-dependent (i.e., type III) FR is observed in those predator-prey interactions where encounter rates are reduced through some feature of the habitat or prey behavior (e.g., crabs preying upon clams hidden among cobble [Sponaugle and Lawton 1990] or seagrass [Peterson 1982a]). In contrast, an inversely density-dependent (i.e., type II) FR likely characterizes predator-prey interactions where prey have developed mechanisms that increase the predator's handling time as an evolutionary tactic (e.g., morphological structures such as a thick shell or heavy ornamentation as found in barnacles [Katz 1985] or oysters [Eggleston $1990 a, b])$.

\section{Predation and habitat type}

In our experiments, habitat type affected the FR of predators. Prey refuges from predation can result from either biological processes or physical factors affected by habitat including deep burial (Blundon and Kennedy 1982b, Hines and Comtois 1985), seagrass beds, roots or rhizomes (Heck and Thoman 1981, Peterson 1982a), other macrofauna (Woodin 1978, Skilleter 1994), water depth relative to predation risk of predators (Micheli 1997), hypoxia (Taylor and Eggleston 2000), and sediments that impede predator foraging (e.g., shell hash or coarse sediments; Sponaugle and Lawton 1990, Skilleter 1994). For instance, in the Rhode River of Chesapeake Bay, Macoma did not survive, even at low densities, when burial depths were shallower than $10 \mathrm{~cm}$, allowing easy predator accessibility (Hines and Comtois 1985). In contrast, when there was some refuge afforded by the habitat, bivalve prey survived, such as when a refuge from predation was obtained by Macoma and Mya (Skilleter 1994), and the hard clam Mercenaria mercenaria (Sponaugle and Lawton 1990) living amid loose shell material, live thick-shelled bivalves Rangia cuneata, or artificial bivalves.

Complex habitats can increase prey survival by decreasing predator efficiency (Heck and Thoman 1981, Marinelli and Coull 1987, Russo 1987). For instance, Pacific and Atlantic shorebirds avoided foraging on mudflats with high sand content, but fed efficiently in nearby flats with a low sand content (Myers et al. 1980, Quammen 1982, 1984, Grant 1984). Habitat complexity reduced encounter rates for gastropods on sea hares (Pennings 1990), for sculpins on stoneflies (Haro and Brusven 1994), and for cod on crustacean prey (Isaksson et al. 1994). Risk of predation by avian predators in shallow water reduced foraging rates by blue crabs upon hard clams, Mercenaria mercenaria (Micheli 

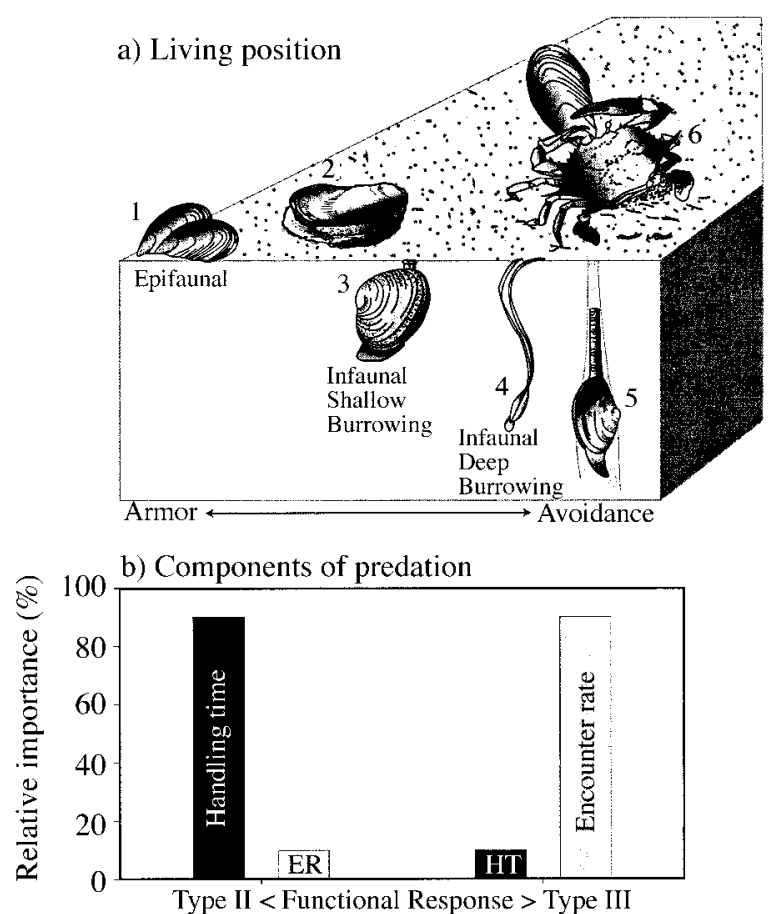

c) Functional response

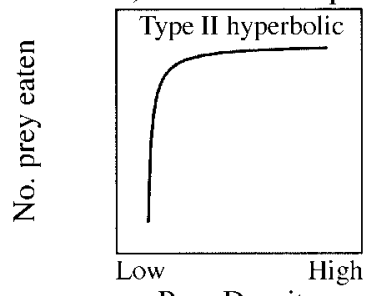

Prey Density

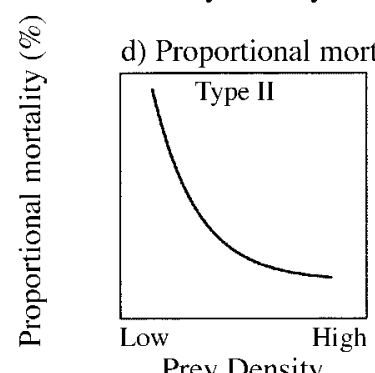

Prey Density

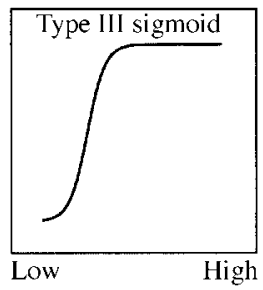

Prey Density

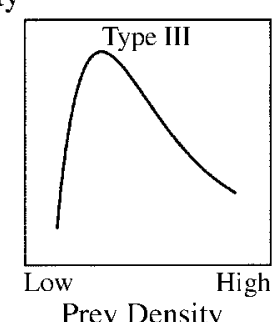

FIG. 8. Conceptual model of the association between antipredator defenses (i.e., armor and avoidance), living position (i.e., epifaunal or infaunal, both shallow- and deep-burrowing) of bivalve molluscs, the relative importance of the basic components of predation (i.e., handling time and encounter rate), the functional response, and proportional mortality. Panels on the left side of all graphs correspond to armored prey, whereas panels on the right side refer to prey utilizing avoidance as a defense tactic. (a) Living position of prey ranging from those with armor, such as (1) the epifaunal mussel Mytilus and (2) oyster Crassostrea, to (3) the infaunal shallow-burrowing hard clam Mercenaria and (4) deep-burrowing clams Macoma balthica and (5) Mya arenaria, which are preyed upon by (6) the blue crab, Callinectes sapidus. (b) Components of predation (i.e., handling time (HT) and encounter rate (ER); Hassell 1979) and their relative importance along a range of antipredator tactics from armor to avoidance.
1997). Thus, predation is strongly mediated by habitat type, often through changes in predator-prey encounter rates.

\section{Functional responses and the evolution of armor and avoidance in bivalve molluscs}

Survival of prey often depends on reducing predation by either increasing a predator's handling time with a morphological barrier ("armor," e.g., a thick shell; Vermeij 1987), or reducing a predator's encounter rate by adapting a low-density or habitat refuge ("avoidance," e.g., residence among shell debris; Sponaugle and Lawton 1990). A major group of marine benthic prey of soft-bottom habitats-deep-burrowing bivalves - have not been investigated experimentally in the field. Furthermore, despite the comparatively broad variation in predator FRs and antipredator tactics, there have been no syntheses of the relationships between these two fundamental aspects of predator-prey dynamics.

We propose a generalized conceptual model detailing the relative importance of behavior, morphology, habitat features, and the basic components of predatorprey interactions to predation-induced mortality of bivalve molluscs (Fig. 8). Vermeij (1987) suggests two major modes of antipredator defense in marine gastropods, cephalopods, arthropods and bivalves: armor or locomotion (more generally, armor or avoidance; Fig. 8a). In our conceptual model, this dichotomy in morphology and behavior associated with antipredator tactics derives from differential emphasis on either increasing the handling time (via armor) or reducing the encounter rate (via avoidance) of predators (Fig. 8b). Bivalves are adapted for either an infaunal or epifaunal lifestyle (Stanley 1970), and these adaptations minimize predation.

On one extreme are prey such as mussels and oysters (Fig. 8a, species 1 and 2) using shell ornamentation, morphology, and thickness to reduce the handling ef-

$\leftarrow$

Handling time is relatively more important in prey employing armor (e.g., morphological size refuge) as an antipredator tactic, whereas factors affecting encounter rate (e.g., habitat structure, low densities) become more important for prey using avoidance as an antipredator tactic. (c) The functional response changes form from inversely density dependent (type II) in prey utilizing armor to density dependent (type III) in prey using avoidance or burrowing. Note that the number of prey eaten at low prey densities is higher in the type II response than in the type III response. (d) Proportional mortality of prey ranging from inversely density dependent to density dependent. Note the low-density refuge from predation with the type III (density-dependent) extreme characterizing species using avoidance, burrowing, or habitat refuges from predation. The model predicts that predators foraging on bivalves living on or near the sediment surface will exhibit a type II functional response, but those foraging on deep-burrowing prey with a low encounter rate will exhibit a type III functional response. 
ficiency of predators including crabs (Fig. 8a, species $6)$. These prey species are generally epifaunal or shallow burrowing, and, if solitary (Lin 1989, Eggleston $1990 a, b)$ or without habitat refuge, they have predators that exhibit an inversely density-dependent (type II) FR (Table 1, Fig. 8c, d). Armor may also provide additional benefits to the organism such as protection from mechanical stress (e.g., for intertidal Donax with thicker, heavier shells than subtidal populations; Donn 1990). Furthermore, shell morphology exhibits phenotypic plasticity in response to a mollusc's vulnerability to predation (Trussel 1996). This plasticity suggests that increases in handling time due to armor are not fixed but flexible. These armored bivalves are in "coexistence refugia," since they are in contact with predators (Menge and Lubchenco 1981).

On the other extreme of the model are bivalve molluscs such as thin-shelled clams (Fig. 8a, species 4 and 5 ), which reduce encounter rates with predators by using deep burial, residence in low-density patches, and protection by habitat structure. These species are usually deep-burrowing infauna with predators that display a density-dependent (type III) FR (Table 1, Fig. 8). These deep burrowers are in "noncoexistence refugia," since they avoid predators (Menge and Lubchenco 1981).

At the midpoint of the armor-avoidance dichotomy lie species that may use both predator avoidance strategies. For example, the hard clam, Mercenaria mercenaria, is a hard-shelled, shallow-burrowing infaunal species. Infaunal species residing shallow in the sediment, such as the hard clam (Fig. 8a, species 3), occasionally experience inversely density-dependent predation and may rely more on shell armor and habitat structure as protection from predation (Horwood and Goss-Custard 1977, Peterson 1982b, Sponaugle and Lawton 1990). Conversely, some of the hard clam's predators may exhibit a density-dependent (type III) FR (Micheli 1997). This intermediate species can therefore represent either end of the model, depending upon habitat structure and the predator (Fig. 8).

Both strategies (i.e., armor or avoidance) emphasize rapid growth to achieve the relative refuges (in shell thickness or burial depth) from predation, or rapid reproduction for smaller species unable to achieve refuges from predation. The depth of burial correlates directly with clam size (Blundon and Kennedy 1982a, $b)$. For example, as prey size increases in Littorina and Nucella, the incidence of successful crab attacks decreases (Hughes and Elner 1979, Elner and Raffaelli 1980, Lawton and Hughes 1985). Furthermore, armor effectiveness increases with shell length for both gastropods (Vermeij 1980) and mussels (Mytilus californianus; Dayton 1971, Suchanek 1978).

In conclusion, we present a test of density-dependent predation in soft-bottom subtidal marine species with contrasting distribution and abundance patterns across various habitats. Specifically, our field evidence sug- gests that two species of thin-shelled infaunal bivalves, both vulnerable to blue crab predation, survive well in various habitats due to a density-dependent "guild functional response" of the predators. Thin-shelled bivalves without protective armor reduce predator encounter rates, in contrast to other armored bivalves that apparently emphasize reduction in predator handling efficiency. Thus, our theoretical model combines our work with previous experimental work to serve as a template for future investigations on density-dependent predator-prey relationships.

\section{ACKNOWLEDGMENTS}

We thank personnel of the Crustacean Ecology program at the Virginia Institute of Marine Science, and of the Smithsonian Environmental Research Center for able field assistance. Comments by Emmett Duffy, Mark Luckenbach, Bruce Menge, Fiorenza Micheli, Tony Underwood, Gerry Vermeij, and two anonymous reviewers on an earlier version improved the manuscript substantially. Funding was provided by the National Science Foundation, the Smithsonian Environmental Sciences Program, the Commonwealth of Virginia, a predoctoral fellowship to R. D. Seitz from the American Association of University Women, and support from the National Estuarine Research Reserve System in Virginia. This paper is contribution number 2345 from the Virginia Institute of Marine Science, Gloucester Point, Virginia.

\section{Literature Cited}

Abrams, P. A. 1982. Functional responses of optimal foragers. American Naturalist 120:382-390.

Abrams, P. A. 1984. Foraging time optimization and interactions in food webs. American Naturalist 124:80-96.

Abrams, P. A. 2000. The evolution of predator-prey interactions: theory and evidence. Annual Review of Ecology and Systematics 31:79-105.

Alexander, S. K. 1986. Diet of the blue crab, Callinectes sapidus Rathbun, from nearshore habitats of Galveston Island. Texas Journal of Science 38:85-89.

Appledorn, R. S. 1983. Variation in the growth rate of Mya arenaria and its relationship to the environment as analyzed through principal components analysis and the omega parameter of the von Bertalanffy equation. U.S. National Marine Fisheries Service Fishery Bulletin 81:75-84.

Arnold, S. K. 1984. The effects of prey size, predator size and sediment composition on the rate of predation of the blue crab, Callinectes sapidus Rathbun, on the hard clam, Mercenaria mercenaria (Linne). Journal of Experimental Marine Biology and Ecology 80:207-219.

Barbeau, M. A., R. E. Sheibling, B. G. Hatcher, L. H. Taylor, and A. W. Hennigar. 1994. Survival analysis of tethered juvenile sea scallops Placopecten magellanicus in field experiments: effects of predators, scallop size and density, site and season. Marine Ecology Progress Series 115:243256.

Bell, S. S., E. D. McCoy, and H. R. Mushinsky, editors. 1991. Habitat structure. The physical arrangement of objects in space. Chapman and Hall, New York, New York, USA

Bertness, M. D., and E. Grosholz. 1985. Population dynamics of the ribbed mussel, Geukensia demissa: the costs and benefits of an aggregated distribution. Oecologia 67:192204.

Blundon, J. A., and V. S. Kennedy. 1982a. Mechanical and behavioral aspects of blue crab, Callinectes sapidus (Rathbun), predation on Chesapeake Bay bivalves. Journal of Experimental Marine Biology and Ecology 56:47-65.

Blundon, J. A., and V. S. Kennedy. 1982b. Refuges for infaunal bivalves from blue crab, Callinectes sapidus (Rath- 
bun), predation in Chesapeake Bay. Journal of Experimental Marine Biology and Ecology 56:67-81.

Boesch, D. F. 1977. A new look at the zonation of benthos along the estuarine gradient. Pages 245-266 in B. C. Coull, editor. Ecology of marine benthos. Belle W. Baruch Marine Library in Marine Science. Volume 6. University of South Carolina Press, Columbia, South Carolina, USA.

Boulding, E. G., and T. K. Hay. 1984. Crab response to prey density can result in density-dependent mortality of clams. Canadian Journal of Fisheries and Aquatic Sciences 41: 521-525.

Charnov, E. L. 1974. Optimal foraging, the marginal value theorem. Theoretical Population Biology 9:129-136.

Clark, M. E., T. G. Wolcott, D. L. Wolcott, and A. H. Hines. 1999a. Foraging and agonistic activity co-occur in freeranging blue crabs (Callinectes sapidus): observation of animals by ultrasonic telemetry. Journal of Experimental Marine Biology and Ecology 233:143-160.

Clark, M. E., T. G. Wolcott, D. L. Wolcott, and A. H. Hines. 1999b. Intraspecific interference among foraging blue crabs Callinectes sapidus: interactive effects of predator density and prey patch distribution. Marine Ecology Progress Series 178:69-78.

Colton, T. 1987. Extending functional response models to include a second prey type: an experimental test. Ecology 68:900-912.

Commito, J. A. 1982. Effects of Lunatia heros predation on the population dynamics of Mya arenaria and Macoma balthica in Maine, USA. Marine Biology 69:187-193.

Cory, R. L., and J. M. Redding. 1977. Mortalities caused by tropical storm Agnes to clams in the Rhode River area of Chesapeake Bay. Pages 478-487 in E. P. Ruzecki, J. R. Schubel, R. J. Huggett, A. M. Anderson, M. L. Wass, R. J. Marasco, and M. P. Lynch. The effects of tropical storm Agnes on the Chesapeake Bay estuarine system. Chesapeake Research Consortium, Publication No. 54. Johns Hopkins University Press, Baltimore, Maryland, USA.

Dayton, P. K. 1971. Competition, disturbance and community organization: the provision and subsequent utilization of space in a rocky intertidal community. Ecological Monographs 41:351-389.

Dayton, P. K. 1984. Processes structuring some marine communities: are they general? Pages 181-197 in D. R. Strong, Jr., D. Simberloff, L. G. Abele, and A. B. Thistle, editors. Ecological communities: conceptual issues and the evidence. Princeton University Press, Princeton, New Jersey, USA.

Dittel, A. I., A. H. Hines, G. M. Ruiz, and K. K. Ruffin. 1995. Effects of shallow water refuge on behavior and densitydependent mortality of juvenile blue crabs in Chesapeake Bay. Bulletin of Marine Science 57:902-916

Donn, T. E., Jr. 1990. Morphometrics of Donax serra Roeding (Bivalvia:Donacidae) populations with contrasting zonation patterns. Journal of Coastal Research 6:893-901.

Ebersole, E. L., and V. S. Kennedy. 1995. Prey preferences of blue crabs Callinectes sapidus feeding on three bivalve species. Marine Ecology Progress Series 118:167-177.

Eggleston, D. B. 1990a. Functional responses of blue crabs Callinectes sapidus Rathbun feeding on juvenile oysters Crassostrea virginica (Gmelin): effects of predator sex and size, and prey size. Journal of Experimental Marine Biology and Ecology 143:73-90.

Eggleston, D. B. 1990b. Behavioral mechanisms underlying variable functional responses of blue crabs, Callinectes sapidus feeding on juvenile oysters, Crassostrea virginica. Journal of Animal Ecology 59:615-630.

Eggleston, D. B., and D. A. Armstrong. 1995. Pre- and postsettlement determinants of estuarine Dungeness crab recruitment. Ecological Monographs 65:193-216.

Eggleston, D. B., R. N. Lipcius, and A. H. Hines. 1992.
Density-dependent predation by blue crabs upon infaunal clam species with contrasting distribution and abundance patterns. Marine Ecology Progress Series 85:55-68.

Elner, R. W., and D. G. Raffaelli. 1980. Interactions between two marine snails, Littorina rudis Maton and Littorina nigrolineata Gray, a predator, Carcinus maenas (L.), and the parasite, Microphallus similis Jagerskiold. Journal of Experimental Marine Biology and Ecology 43:151-160.

Ens, B. J., and J. D. Goss-Custard. 1984. Interference among oystercatchers, Haematopus ostralegus, feeding on mussels, Mytilus edulis, on the Exe Estuary. Journal of Animal Ecology 53:217-231.

Grant, J. 1984. Sediment microtopography and shorebird foraging. Marine Ecology Progress Series 19:293-296.

Haddon, M., R. G. Wear, and H. A. Packer. 1987. Depth and density of burial by the bivalve Paphies ventricosa as refuges from predation by the crab Ovalipes catharus. Marine Biology 94:25-30.

Haro, R. J., and M. A. Brusven. 1994. Effects of cobble embeddedness on the microdistribution of the sculpin Cottus beldingi and its stonefly prey. Great Basin Naturalist 54:64-70.

Hassell, M. P. 1979. The dynamics of arthropod predatorprey systems. Monographs in Population Biology 13. Princeton University Press, Princeton, New Jersey, USA.

Hassell, M. P., J. H. Lawton, and J. R. Beddington. 1977. Sigmoid functional responses by invertebrate predators and parasitoids. Journal of Animal Ecology 46:249-262.

Heck, K. L., Jr., and L. B. Crowder. 1991. Habitat structure and predator-prey interactions in vegetated aquatic systems. Pages 281-299 in S. S. Bell, E. D. McCoy, and H. R. Mushinsky, editors. Habitat structure. The physical arrangement of objects in space. Chapman and Hall, New York, New York, USA.

Heck, K. L., and T. A. Thoman. 1981. Experiments on predator-prey interactions in vegetated aquatic habitats. Journal of Experimental Marine Biology and Ecology 53:125-134.

Hines, A. H., and K. Comtois. 1985. Vertical distribution of estuarine infauna in sediments of central Chesapeake Bay. Estuaries 8:251-261.

Hines, A. H., P. J. Haddon, J. J. Miklas, L. A. Wiechert, and A. M. Haddon. 1987. Estuarine invertebrates and fish: sampling design and constraints for long-term measurements of population dynamics. Pages 140-164 in T. P. Boyle, editor. New approaches to monitoring aquatic ecosystems. ASTM STP 940, American Society of Testing and Materials. Philadelphia, Pennsylvania, USA.

Hines, A. H., A. M. Haddon, and L. A. Wiechert. 1990. Guild structure and foraging impact of blue crabs and epibenthic fish in a subestuary of Chesapeake Bay Marine Ecology. Progress Series 67:105-126.

Hines, A. H., and J. S. Pearse. 1982. Abalones, shells and sea otters: dynamics of prey populations in central California. Ecology 63:1547-1560.

Hines, A. H., R. B. Whitlatch, S. F. Thrush, J. E. Hewitt, V. J. Cummings, P. K. Dayton, and P. Legendre. 1997. Nonlinear foraging response of a large marine predator to benthic prey: eagle ray pits and bivalves in a New Zealand sandflat. Journal of Experimental Marine Biology and Ecology 216:191-210.

Holland, A. F. 1985. Long-term variation in macrobenthos in the mesohaline region of Chesapeake Bay. Estuaries 8: 93-113.

Holland, A. F., N. K. Mountford, M. H. Hiegel, K. R. Kaumeyer, and K. A. Mihursky. 1980. Influence of predation on infaunal abundance in upper Chesapeake Bay, USA. Marine Biology 57:221-235.

Holling, C. S. 1959. The components of predation as revealed by a study of small mammal predation of the European pine sawfly. Canadian Journal of Entomology 91:293-320. 
Holling, C. S. 1965. The functional response of predators to prey density and its role in mimicry and population regulation. Memoirs of the Entomological Society of Canada 45:3-60.

Horwitz, R. J. 1987. Fish. Pages 167-225 in K. L. Heck, editor. Ecological studies in the middle reach of Chesapeake Bay, Calvert Cliffs. Volume 23. Lecture notes on coastal and estuarine studies. Springer-Verlag, New York, New York, USA.

Horwood, J. W., and J. D. Goss-Custard. 1977. Predation by the oystercatcher, Haematopus ostralegus (L.), in relation to the cockle, Cerastoderma edule (L.), fishery in the Burry Inlet, South Wales. Journal of Applied Ecology 14:139158.

Hughes, R. N., and R. W. Elner. 1979. Tactics of a predator, Carcinus maenus, and morphological responses of the prey, Nucella lapillus. Journal of Animal Ecology 48:65-78.

Iribarne, O., D. Armstrong, and M. Fernandez. 1995. Environmental impact of intertidal juvenile Dungeness crab habitat enhancement: effects on bivalves and crab foraging rate. Journal of Experimental Biology and Ecology 192: 173-194.

Isaksson, I., L. Pihl, and J. van Montfrans. 1994. Eutrophication-related changes in macrovegetation and foraging of young cod (Gadus morhua L.): a mesocosm experiment. Journal of Experimental Biology and Ecology 177:203217.

Katz, C. H. 1985. A nonequilibrium marine predator-prey interaction. Ecology 66:1426-1438.

Laughlin, R. A. 1982. Feeding habits of the blue crab, Callinectes sapidus Rathbun, in the Apalachicola estuary, Florida. Bulletin of Marine Science 32:807-822.

Lawton, P., and R. N. Hughes. 1985. Foraging behaviour of the crab Cancer pagurus feeding on the gastropods Nucella lapillus and Littornia littorea: comparisons with optimal foraging theory. Marine Ecology Progress Series 27:143154.

Levitan, D. R. 1991. Influence of body size and population density on fertilization success and reproductive output in a free-spawning invertebrate. Biological Bulletin of the Marine Biological Laboratory, Woods Hole 181:261-268.

Lin, J. 1989. Influence of location in the salt marsh on survivorship of ribbed mussels. Marine Ecology Progress Series 56:105-110.

Lindquist, N., and M. E. Hay. 1995. Can small rare prey be chemically defended? The case for marine larvae. Ecology 76:1347-1358.

Lipcius, R. N., D. B. Eggleston, D. L. Miller, and T. C. Luhrs. 1998. The habitat-survival function for Caribbean spiny lobster: an inverted size effect and non-linearity in mixed algal and seagrass habitats. Marine and Freshwater Research 49:807-816.

Lipcius, R. N., and A. H. Hines. 1986. Variable functional responses of a marine predator in dissimilar homogeneous microhabitats. Ecology 67:1361-1371.

Lipcius, R. N., and W. A. Van Engel. 1990. Blue crab population dynamics in Chesapeake Bay: variation in abundance (York River, 1972-1988) and stock-recruit functions. Bulletin of Marine Science 46:180-194.

Mansour, R. A. 1992. Foraging ecology of the blue crab, Callinectes sapidus Rathbun, in lower Chesapeake Bay. Dissertation. The College of William and Mary, Virginia Institute of Marine Science, Gloucester Point, Virginia, USA.

Mansour, R. A., and R. N. Lipcius. 1991. Density-dependent foraging and mutual interference in blue crabs preying upon infaunal clams. Marine Ecology Progress Series 72:239246.

Marinelli, R. L., and B. C. Coull. 1987. Structural complexity and juvenile fish predation on meiobenthos: an experimen- tal approach. Journal of Experimental Marine Biology and Ecology 108:67-81.

Matthiessen, G. C. 1960. Intertidal zonation in populations of Mya arenaria. Limnology and Oceanography 5:381388

Menge, B. A. 1995. Indirect effects in marine rocky intertidal interaction webs: patterns and importance. Ecological Monographs 65:21-74.

Menge, B. A., and T. Farrell. 1989. Community structure and interaction webs in shallow marine hard-bottom communities: tests of an environmental stress model. Advances in Ecological Research 18:189-162.

Menge, B. A., and J. Lubchenco. 1981. Community organization in temperate and tropical rocky intertidal habitats: prey refuges in relation to consumer pressure gradients. Ecological Monographs 51:429-450.

Menge, B. A., and J. P. Sutherland. 1976. Species diversity gradients: synthesis of the roles of predation, competition, and temporal heterogeneity. American Naturalist 110:351369.

Menge, B. A., and J. P. Sutherland. 1987. Community regulation: variation in disturbance, competition, and predation in relation to environmental stress and recruitment. American Naturalist 130:730-757.

Micheli, F. 1997. Effects of predator foraging behavior on patterns of prey mortality in marine soft bottoms. Ecological Monographs 67:203-224.

Murdoch, W. W. 1994. Population regulation in theory and practice. Ecology 75:271-287.

Murdoch, W. W., and A. Oaten. 1975. Predation and population stability. Advances in Ecological Research 9:1-131.

Myers, J. P., S. L. Williams, and F. A. Pitelka. 1980. An experimental analysis of prey availability for sanderlings (Aves: Scolopacidae) feeding on sandy beach crustaceans. Canadian Journal of Zoology 58:1564-1574.

Oaten, A., and W. W. Murdoch. 1975. Switching, functional response, and stability in predator-prey systems. American Naturalist 109:299-318.

Paine, R. T. 1966. Food web complexity and species diversity. American Naturalist 100:65-75.

Paine, R. T. 1984. Ecological determinism in the competition for space Ecology 65:1339-1348.

Pennings, S. C. 1990. Predator-prey interactions in opisthobranch gastropods: effects of prey body size and habitat complexity. Marine Ecology Progress Series 62:95-101.

Peterson, C. H. 1979. The importance of predation and competition in organizing the intertidal epifaunal communities of Barnegat Inlet, New Jersey. Oecologia (Berlin) 39:1-24.

Peterson, C. H. 1982a. Clam predation by whelks (Busycon spp.): experimental tests of the importance of prey size, prey density and seagrass cover. Marine Biology 66:159170.

Peterson, C. H. 1982b. The importance of predation and intraand interspecific competition in the population biology of two infaunal suspension-feeding bivalves, Protothaca staminea and Chione undatella. Ecological Monographs 52: 437-475.

Peterson, C. H., and R. Black. 1988. Density-dependent mortality caused by physical stress interacting with biotic history. American Naturalist 131:257-270, 437-475.

Peterson, C. H., and G. A. Skilleter. 1994. Control of foraging behavior of individuals within an ecosystem context: the clam Macoma balthica, flow environment and siphon-cropping fish. Oecologia 100:256-267.

Piersma, T., J. Van Gils, P. De Goeij, and J. van der Meer. 1995. Holling's functional response model as a tool to link the food-finding mechanism of a probing shorebird with its spatial distribution. Journal of Animal Ecology 64:493504. 
Pyke, G. H. 1984. Optimal foraging theory: a critical review. Annual Review of Ecology and Systematics 15:523-575.

Quammen, M. L. 1982. Influence of subtle substrate differences on feeding by shorebirds on intertidal mudflats. Marine Biology 71:339-343.

Quammen, M. L. 1984. Predation by shorebirds, fish, and crabs on invertebrates in intertidal mudflats: an experimental test. Ecology 65:529-537.

Rhoads, D. C., and D. K. Young. 1970. The influences of deposit-feeding organisms on sediment stability and community trophic structure. Journal of Marine Research 28: $150-178$.

Ricker, W. E. 1975. Computation and interpretation of biological statistics of fish populations. Bulletin of the Fisheries Beard of Canada 191:1-382.

Russo, A. R. 1987. Role of habitat complexity in mediating predation by the gray damselfish Abudefduf sordidus on epibenthic amphipods. Marine Ecology Progress Series 36: 101-105.

Seitz, R. D. 1996. The role of epibenthic predators in structuring marine soft-bottom communities along an estuarine gradient. Dissertation. The College of William and Mary, Virginia Institute of Marine Science, Gloucester Point, Virginia, USA.

Seitz, R. D., and R. N. Lipcius. 2001. Variation in top-down and bottom-up control of marine bivalves at differing spatial scales. International Council for the Exploration of the Sea (ICES) Journal of Marine Science $\mathbf{5 8 .}$

Seliger, H. H., J. A. Boggs, and W. H. Biggley. 1985. Catastrophic anoxia in the Chesapeake Bay in 1984. Science 228:70-73.

Sih, A., P. Crowley, M. McPeek, J. Petranka, and K. Strohmeier. 1985. Predation, competition, and prey communities: a review of field experiments. Annual Review of Ecology and Systematics 16:269-311.

Sih, A., G. Englund, and D. Wooster. 1998. Emergent impacts of multiple predators on prey. Trends in Ecology and Evolution 13:350-355.

Skilleter, G. A. 1994. Refuges from predation and the persistence of estuarine clam populations. Marine Ecology Progress Series 109:29-42.

Sokal, R. R., and F. J. Rohlf. 1981. Biometry. Second edition. W. H. Freeman, San Francisco, California, USA.

Solomon, M. E. 1949. The natural control of animal populations. Journal of Animal Ecology 18:1-35.

Sponaugle, S., and P. Lawton. 1990. Portunid crab predation on juvenile hard clams: effects of substrate type and prey density. Marine Ecology Progress Series 67:43-53.

Stanley, S. M. 1970. Relation of shell form to life habits of the Bivalvia (Mollusca). Geological Society of America Memoirs 125:1-296.

Stephens, D. W., and J. R. Krebs, editors. 1986. Foraging theory. Princeton University Press, Princeton, New Jersey, USA.

Suchanek, T. H. 1978. The ecology of Mytilus edulis L. in exposed rocky intertidal communities. Journal of Experimental Marine Biology and Ecology 31:105-120.

Taylor, D. L., and D. B. Eggleston. 2000. Effects of hypoxia on an estuarine predator-prey interaction: foraging behavior and mutual interference in the blue crab, Callinectes sapidus, and the infaunal clam prey, Mya arenaria. Marine Ecology Progress Series 196:221-237.

Trussell, G. C. 1996. Phenotypic plasticity in an intertidal snail: the role of a common crab predator. Evolution 50: 448-454.

Ulanowicz, R. E., M. L. Ali, A. Vivian, D. R. Heinle, W. A. Richkus, and J. K. Summers. 1982. Identifying climatic factors influencing commercial fish and shellfish landings. U.S. National Marine Fisheries Service Fisheries Bulletin 80:611-619.

Underwood, A. J. 1997. Experiments in ecology: their logical design and interpretation using analysis of variance. Cambridge University Press, Cambridge, UK.

Vermeij, G. J. 1980. Drilling predation in a population of the edible bivalve Anadara granosa. Nautilus 94:123-125.

Vermeij, G. J. 1987. Evolution and escalation: an ecological history of life. Princeton University Press, Princeton, New Jersey, USA.

Vermeij, G. J. 1994. The evolutionary interaction among species: selection, escalation and coevolution. Annual Review of Ecology and Systematics 25:219-236.

Virnstein, R. W. 1977. The importance of predation by blue crabs and fishes on benthic infauna in Chesapeake Bay. Ecology 58:1199-1217.

Watanabe, J. M. 1984. The influence of recruitment, competition, and benthic predation on spatial distributions of three species of kelp forest gastropods (Trochidae: Tegula). Ecology 65:920-936.

West, D. L., and A. H. Williams. 1986. Predation by Callinectes sapidus (Rathbun) within Spartina alterniflora (Loisel) marshes. Journal of Experimental Marine Biology and Ecology 100:75-95.

Williams, A. B. 1984. Shrimps, lobsters, and crabs of the Atlantic coast of the eastern United States, Maine to Florida. Smithsonian Institution Press, Washington, D.C., USA.

Wilson, W. H. 1990. Competition and predation in marine soft-sediment communities. Annual Review of Ecology and Systematics 21:221-241.

Witman, J. D. 1985. Refuges, biological disturbance and rocky subtidal community structure in New England. Ecological Monographs 55:421-445.

Woodin, S. A. 1978. Refuges, disturbance, and community structure: a marine soft-bottom example. Ecology 59:274284

Zwarts, L., and J. H. Wanink. 1991. The macrobenthos fraction accessible to waders may represent marginal prey. Oecologia 87:581-587. 